\title{
Typifications, new combinations and new synonyms in Indian Impatiens (Balsaminaceae)
}

\author{
Rajeev Kumar Singh ${ }^{*}$, Dipankar Borah ${ }^{2} \&$ Momang Taram $^{3}$
}

\author{
${ }^{1}$ Botanical Survey of India, Southern Regional Centre, TNAU Campus, Lawley Road, Coimbatore - 641003, Tamil Nadu, India; ORCID: \\ https://orcid.org/0000-0002-0136-9243 \\ ${ }^{2}$ Department of Botany, Goalpara College, Goalpara - 783101, Assam, India; ORCID: https://orcid.org/0000-0002-3016-1070 \\ ${ }^{3}$ Department of Botany, Rajiv Gandhi University, Rono Hills, Doimukh - 791112, Arunachal Pradesh, India; ORCID: https://orcid.org/0000- \\ 0002-4669-615X \\ * corresponding author (e-mail: rksbsiadsingh@gmail.com)
}

\begin{abstract}
One neotype, three second-step lectotypes and fourty lectotypes are designated for fourty four names in Indian Impatiens to fix the identity and to avoid the misapplication of names. Thirty nine names are synonymized, after a detailed ecological study of live plants in the field and examination of herbarium specimens including types. Six new combinations with change in their status are proposed for six taxa.
\end{abstract}

Keywords: endemic, lectotype, neotype, protologue, syntype, variation

\section{Introduction}

The genus Impatiens Riv. ex L. comprises about 1050 species, distributed across the Old World tropics and subtropics as well as in the north and central America (Powo 2020). Most of the Impatiens species occur in five centres of diversity of the Old World, namely Madagascar, tropical Africa, Sino-Himalayan region, Western Ghats region of India and Southeast Asia. So far, about 240 species have been documented for the Indian flora, of which 150 species are endemic and the highest diversity occurs in two regions - northeast India and the Western Ghats (Bhaskar 2012; Singh 2016a, 2016b, 2017; Singh \& Garg 2016; Gogoi et al. 2018, Arigela et al. 2019). While working on the genus Impatiens in India, we realized the necessity of one neotype, three second-step lectotypes and fourty lectotypes fourty four names in Impatiens to fix the identity and to avoid misapplication of names, because no specific herbarium specimen was cited as holotype in the protologue of these names and also yet not typified (Singh 2016a, 2016b, 2017; Ruchisansakun et al. 2018; Gogoi \& Sherpa 2020). The guidelines and recommendations of the Article 9 of the ICN (Turland et al. 2018) have been followed while designating the second-step lectotypes, lectotypes and neotype. The images of the selected lectotypes and neotype specimens kept at the herbaria of E, K and G are available online (https:// data.rbge.org.uk/search/herbarium/, http://apps.kew. org/herbcat/navigator.do and https://www.ville-ge.ch/ musinfo/bd/cjb/chg/index.php?lang=en).

India harbours a wide range of Impatiens species due to its diverse topography, vegetation and forest types. Presently, for the genus Impatiens, Madagascar has a highest species richness with about 260 species (Rahelivololona et al. 2018) and India is at second position with about 240 species. The diversity of climate types and habitats of Indian Himalaya and Western Ghats is associated with Impatiens species diversity and richness. Detailed ecological study of Impatiens species in different habitats (Himalaya and Western Ghats) showed that some species are polymorphic, some show variation in the vegetative morphological traits, some in the reproductive (floral and fruiting) traits, and some in both vegetative and reproductive traits. It is observed that abiotic ecological factors (climatic, edaphic and physiographic) play a major role (up to $95 \%$ ) in the morphological variation of some taxa, while biotic factors play a minor role (up to 5\%). After a detailed study of protologues, relevant literature, and herbarium 
specimens, including types and live plants in the field, thirty nine names are synonymized under respective recognized species. Six new combinations with change in their status are also proposed for six taxa.

The acronyms of herbaria mentioned in this work are according to http://sweetgum.nybg.org/science/ih/.

\section{Typifications, new combinations and new synonyms}

1. Impatiens arguta Hook. f. \& Thomson in J. Proc. Linn. Soc., Bot. 4: 137. 1859.

Type citation in the protologue: "Hab. Umbrosis Himalayae orientalis temperatae et subtropicae; Sikkim, alt. 5000-7000 ped.! J. D. H.; Mont. Khasiae, alt. 3000-6000 ped.! Lobb, \& c. (fl. Jun.-Oct.). (v.v.)".

L e c t o ty pe (designated by Ruchis. et al. in Blumea 63: 232. 2018): India, Sikkim, Darjeeling (now in West Bengal state), $7500 \mathrm{ft}$., s.d., Impatiens no. 101, J.D. Hooker s.n. (K000694618!); isolectotype K000694619!.

Re maining syntypes: India, Sikkim, 7000 ft., s.d., Impatiens no. 101, J.D. Hooker 188 (K000694620!); India, Sikkim, 5000-7000 ft., s.d., Impatiens no. 101, J.D. Hooker s.n. (CAL!, G00237326!, G00237329!, L0249094!, M0211777!, MH64261!, NY00006757!, P04542746!, P04542751!, S11-15955!); India, Khasia, 4000-6000 ft., s.d., Impatiens no. 101, J.D. Hooker \& T. Thomson s.n. (B100365169!, B100365170!, G00237327!, G00237328!, L0249092!, L0249096!, M0211776!, MH64263!, MPU019012!, P04542748!, P05029188!, S-G-3349!, U1149122!).

I. acmanthera Hook. f. in Rec. Bot. Surv. India 4: 17, 22. 1905, syn. nov.

Type citation in the protologue: "Sikkim, alt. 6,000 ft".

L e c t o ty pe (designated here): India, Sikkim, 6000 ft., 1878, G. King s.n. (right hand side specimen of K000694630!); isolectotypes CAL! - other two specimens of K000694630!.

I. arguta var. bulleyana Hook. f. in Hooker's Icon. P1. 29: t. 2875. 1908.

Type citation in the protologue: "China: Yunnan; in moist woods near Chen-Twong, G. Forrest, $100 "$ ".

Le c t otype (designated by Ruchis. et al. in Blumea 63: 232. 2018): China, in woods near ChuJung road, 6000-7000 ft., September 1903, G. Forrest 100 (K000694030!); isolectotypes K000694028!, K000694029!.

I. arunachalensis Hareesh, A. Joe, M. Sabu \& Gogoi in Phytotaxa 305: 44. 2017, syn. nov.

Hol otype: India, Arunachal Pradesh, Upper Siang district, Siyat, on the road from Pasighat to
Yingkiong, 11 July 2015, V.S. Hareesh \& A. Joe 143741 (CAL!).

I. gagei Hook. f., Hooker's Icon. Pl. 30: t. 2951. 1911. Type citation in the protologue: "Eastern Himalaya: Darjeeling; Tonglo slopes, below Simana, alt. 6000-8000 ft., Burkill 27743, 27744, 27745".

L e c t o t y pe (designated by Ruchis. et al. in Blumea 63: 232. 2018): India, West Bengal, Darjeeling, under Simana, 6000-8000 ft., 3 October 1906, I.H. Burkill 27744 (K000694617!).

I. manipurensis Hook. f. in Rec. Bot. Surv. India 4: 31, 35. 1905, syn. nov.

Type citation in the protologue: "Manipur".

L e c t o type (designated here): India, Manipur, Karong myang Khong, 3000-5000 ft., May 1882, G. Watt 6755 (upper right hand side specimen of K000694621!); isolectotypes CAL! - other specimens of K000694621!

I. namchabarwensis R.J. Morgan, Y.M. Yuan \& X.J. Ge in Bot. Mag. 22: 206, t. 537. 2005.

H o l o t y pe: China, Xizang, Lengduo, Medog, 930 m, 29 September 2003, Y.M Yuan \& X.J. Ge CN200370 (NEU).

I. roingensis Hareesh, A. Joe \& M. Sabu in Webbia 71: 187. 2016.

H o l o t y p e: India, Arunachal Pradesh, Lower Dibang Valley district, Roing, road to Chidu, 3 July 2015, V.S. Hareesh \& A. Joe 143735 (CALI).

I. spirifera Hook. f. \& Thomson in J. Proc. Linn. Soc., Bot. 4: 135. 1860, syn. nov.

Type citation in the protologue: "Hab. Sylvis temperatis subtropicisque Himalayae orientalis Sikkim, alt. 4000-7000 ped! J. D. H. (fl. Oct.-Dec.). (v.v.)".

L e c t ot y pe (designated by Gogoi et al. in Telopea 20: 23. 2017): India, Sikkim, Choongtam, 4000-5000 ft., 27 October 1849, Impatiens no. 99, J.D. Hooker s.n. K000694933!.

Remaining syntypes: India, Sikkim, 40005000 ft., s.d., Impatiens no. 99, J.D. Hooker s.n. (CAL!, right hand side specimen of L0389740!, P04538448!);

I. tatoensis Gogoi \& W. Adamowski in Telopea 20: 23. 2017, syn. nov.

H o l ot y pe: India, Arunachal Pradesh, West Siang district, between Tato and Menchukha, 30 July 2013, R. Gogoi 30536 (CAL!).

D istribution: Bhutan, China, Myanmar, Nepal and India (northeast Indian states and hilly areas of West Bengal adjacent to Sikkim and Bhutan).

N o t e s: Hooker (1905) described Impatiens acmanthera based on the specimens collected from Sikkim. $\mathrm{He}$ cited only locality information in the protologue, but did not provide the name of collector/s, collection number/s, date of collection/s and name of herbarium 

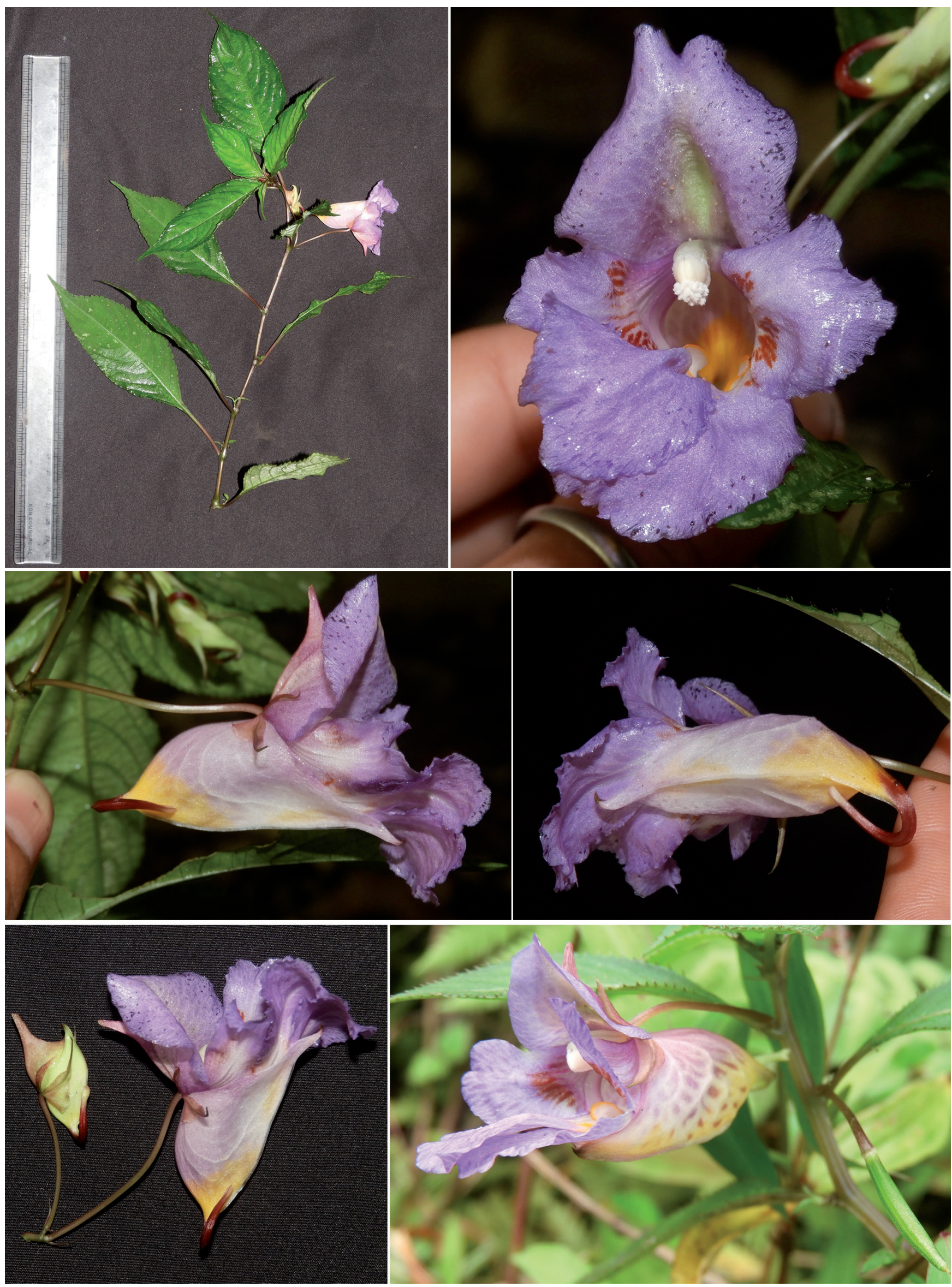

Fig. 1. Impatiens arguta, close-up of flowers from different angles 

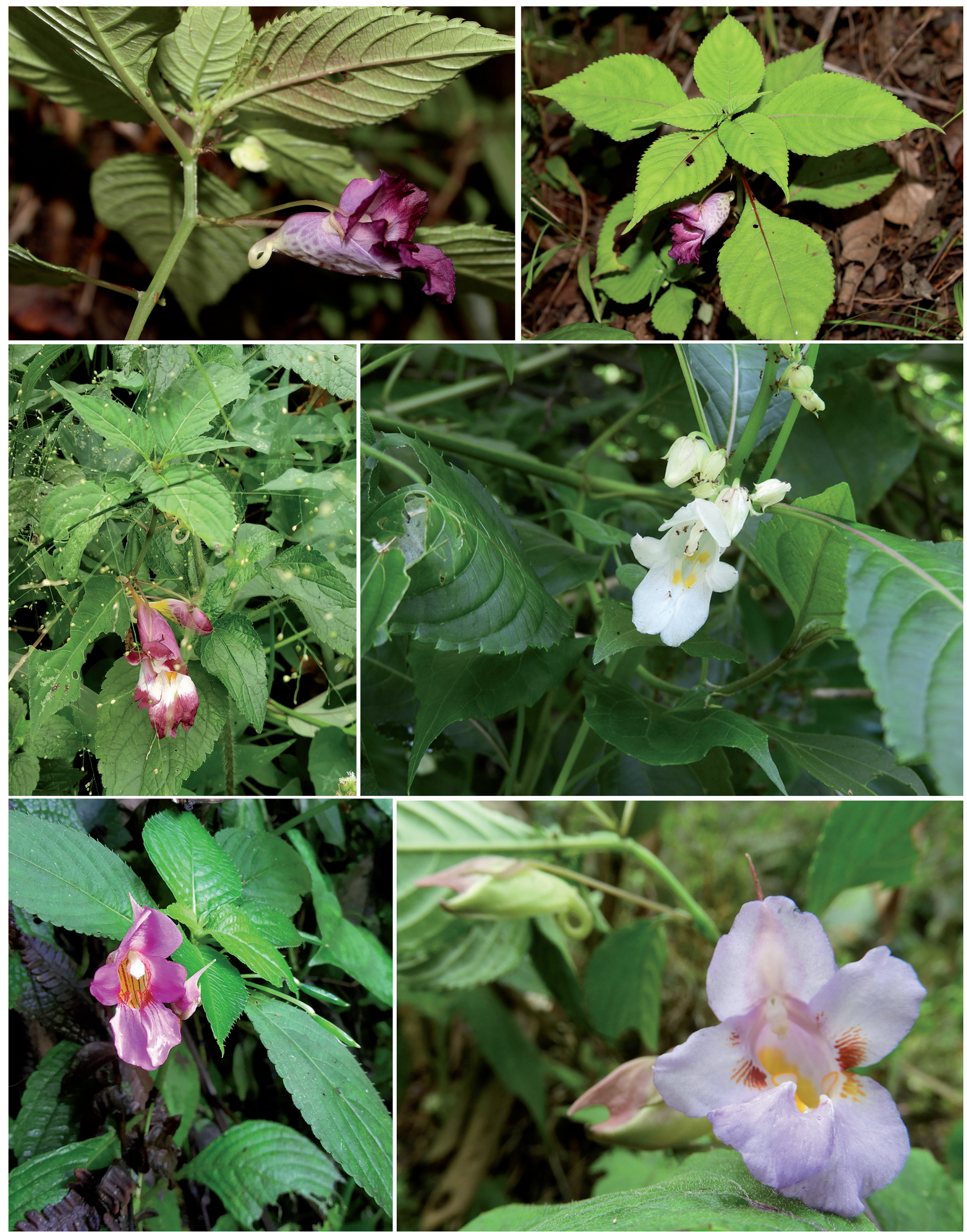

Fig. 2. Impatiens arguta, variation in flower colour 

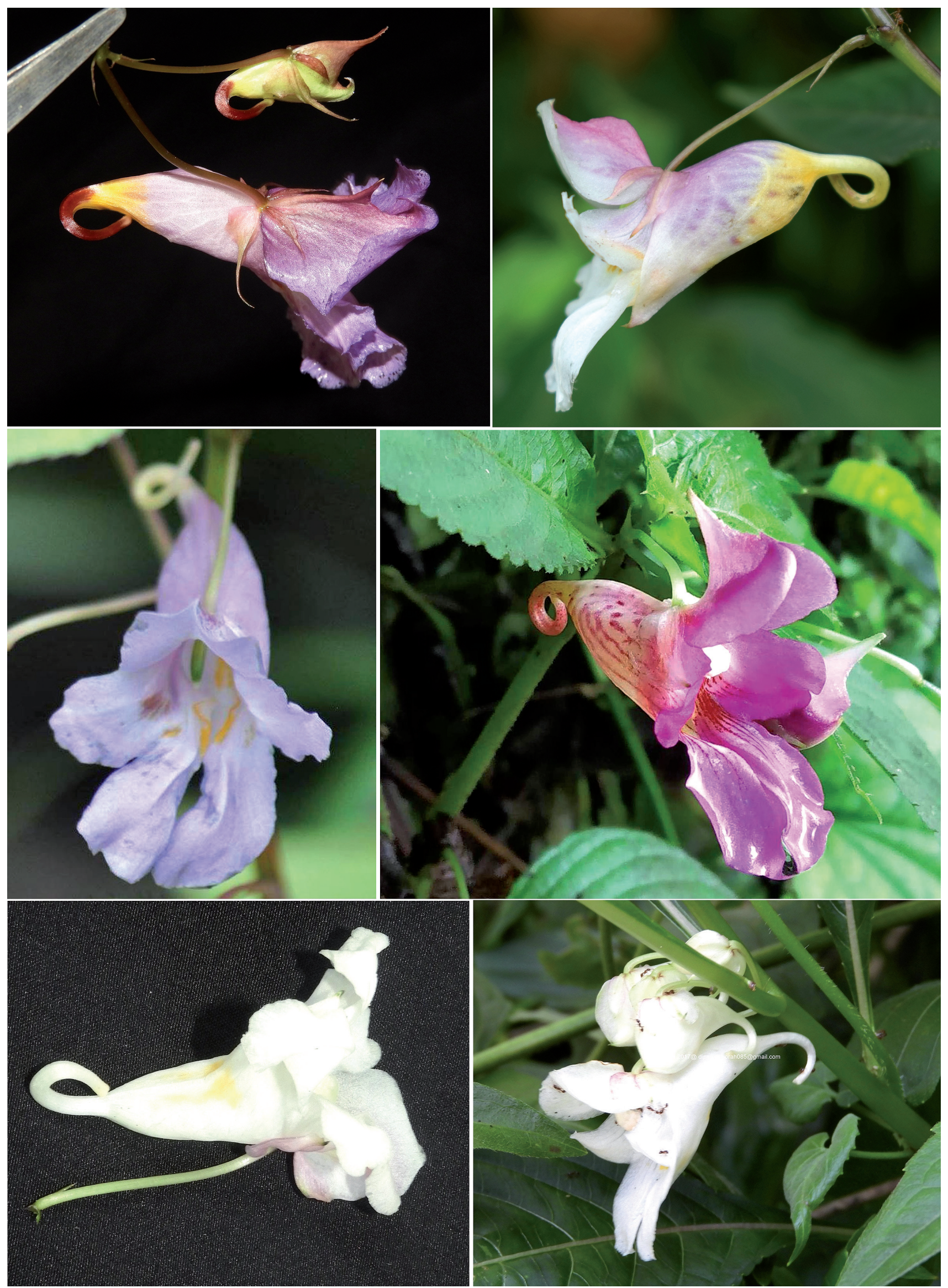

Fig. 3. Impatiens arguta, variation in lower sepals with spur 
where specimens housed. Two original herbarium sheets were traced for the name I. acmanthera Hook. f. (CAL and K000694630). The better preserved, right hand side specimen of K000694630, is designated here as the lectotype. The upper right hand side specimen of K000694621, is designated here as the lectotype for the name I. manipurensis Hook. f.

In I. arguta, variation in flower colour (pure whitepink-lilac-purplish-violet) was observed in different localities of northeast Indian states. There was also observed variation in the size of peduncle (1-7 mm long), spur (12-20 mm long, curved or coiled) and shape and size of dorsal petal (11-27 x 11-22 mm, broad ovateelliptic-orbicular, dorsally cucullate-flat, apex apiculate or mucronate or emarginate, horn-like appendage absent or up to $6 \mathrm{~mm}$ long). I. acmanthera, I. arunachalensis, I. manipurensis, I. spirifera and I. tatoensis are synonymized here under I. arguta, because we did not find any significant constant character to differentiate them from I. arguta. Earlier, these synonymized names were differentiated from I. arguta based on few marginal characters, but these characters are found to be variable over time and space within the populations of living plants at many places of northeast India (Figs. 1-3). The flowering and fruiting times, distribution patterns and habitat preferences of these taxa were found to overlap. It is even difficult to segregate these names at infraspecific level due to overlapping of taxonomical characters.

In earlier works (Grey-Wilson 1991; Chen et al. 2007; Gogoi et al. 2018; Ruchisansakun et al. 2018), the distributional altitude range given for I. arguta is $1200-3200 \mathrm{~m}$, but we found this species at the altitude of 600-3000 $\mathrm{m}$ in northeast India.

2. Impatiens arguta var. walongensis (Hareesh, M. Sabu \& Borah) R. Kr. Singh \& D. Borah, comb. et stat. nov.

I. walongensis Hareesh, M. Sabu \& Borah in Phytotaxa 317: 226. 2017.

H o l o ty pe: India, Arunachal Pradesh, Anjaw district, Walong, 12 May 2016, V.S. Hareesh 143794 (CAL!).

Distribution: Endemic to Arunachal Pradesh, India.

Notes: Impatiens walongensis is very similar to I. arguta in all respects, except the size of peduncle, therefore, treated here as a variety of I. arguta. Peduncle is up to $7 \mathrm{~mm}$ long in I. arguta var. arguta and $10-15 \mathrm{~mm}$ long in var. walongensis.

\section{Impatiens arguta var. wattii (Hook. f. \& Thomson)}

R. Kr. Singh \& D. Borah, comb. et stat. nov.

I. wattii Hook. f. in Rec. Bot. Surv. India 4: 30, 35. 1905.
Type citation in the protologue: "Manipur Hills, alt. 3,000-5,000 ft.".

L e c t o type (designated here): India, Manipur, Karong myang Khong, 3000-5000 ft., May 1882, G. Watt 7131 (middle specimen of K000694899!); isolectotypes K000694898! - other two specimens of K000694899!, BSIS!.

D i stributi on: Endemic to Manipur, India.

Notes: Three original herbarium sheets were traced for the name Impatiens wattii Hook. f. (BSIS, K000694898 and K000694899). From these, the better preserved middle specimen of K000694899 is designated here as the lectotype, as it agrees well with the protologue.

I. wattii is treated here as a variety of I. arguta because the former differs from the later only in the leaf shape. The flower of $I$. wattii is similar to I. arguta in all respects. In I. arguta var. arguta leaves are ovateelliptic and in var. wattii leaves are lanceolate.

4. Impatiens balfourii Hook. f., in Bot. Mag. 129: t. 7878. 1903.

Type citation in the protologue: "The beautiful Balsam here figured was raised from seed sent by Mr. ....., I. Balfourii flowered in the Royal Gardens, Edinburgh, in September and October, 1901".

Lectotype (designated here): India, Jammu \& Kashmir, Cultivated at Royal Botanic Garden, Edinburgh, 21 September 1901, Anon. s.n. (K000694736!); isolectotype K000694735!.

I. flemingii Hook. f. in Rec. Bot. Surv. India 4: 5, 9. 1904, syn. nov.

Type citation in the protologue: "Murree; Kashmir, alt. 6,500-8,000 ft.; and Hazara".

L e c t o t y p e (inadvertently designated by Y.J. Nasir, Fl. Pakistan 133: 10. 1980): Pakistan, Rawalpindi district, Murree Hills, 1895, Jencken s.n. (K000694674!). D istribution: Native of Pakistan and India (Himachal Pradesh, Jammu \& Kashmir and Uttarakhand). This species was first time cultivated in the year 1894 and 1898 at Royal Botanic Gardens, Kew (K000694733 and K000694734) and then in the year 1901 at Royal Botanic Garden, Edinburgh (K000694735 and K000694736). Introduced as ornamental species in Europe, America, Australia and other parts of the world, but now, it has become invasive there (Adamowski 2007, 2009).

N o te s: Hooker $(1903$, l.c.) described Impatiens balfourii on the basis of specimens that flowered in September and October 1901 at Royal Botanic Garden, Edinburgh. In keeping with the practice of the time, he did not designate a holotype nor did he mention the name of the herbarium where these specimens were housed. Two herbarium specimens made from the plants that flowered in September 1901 at Royal Botanic 

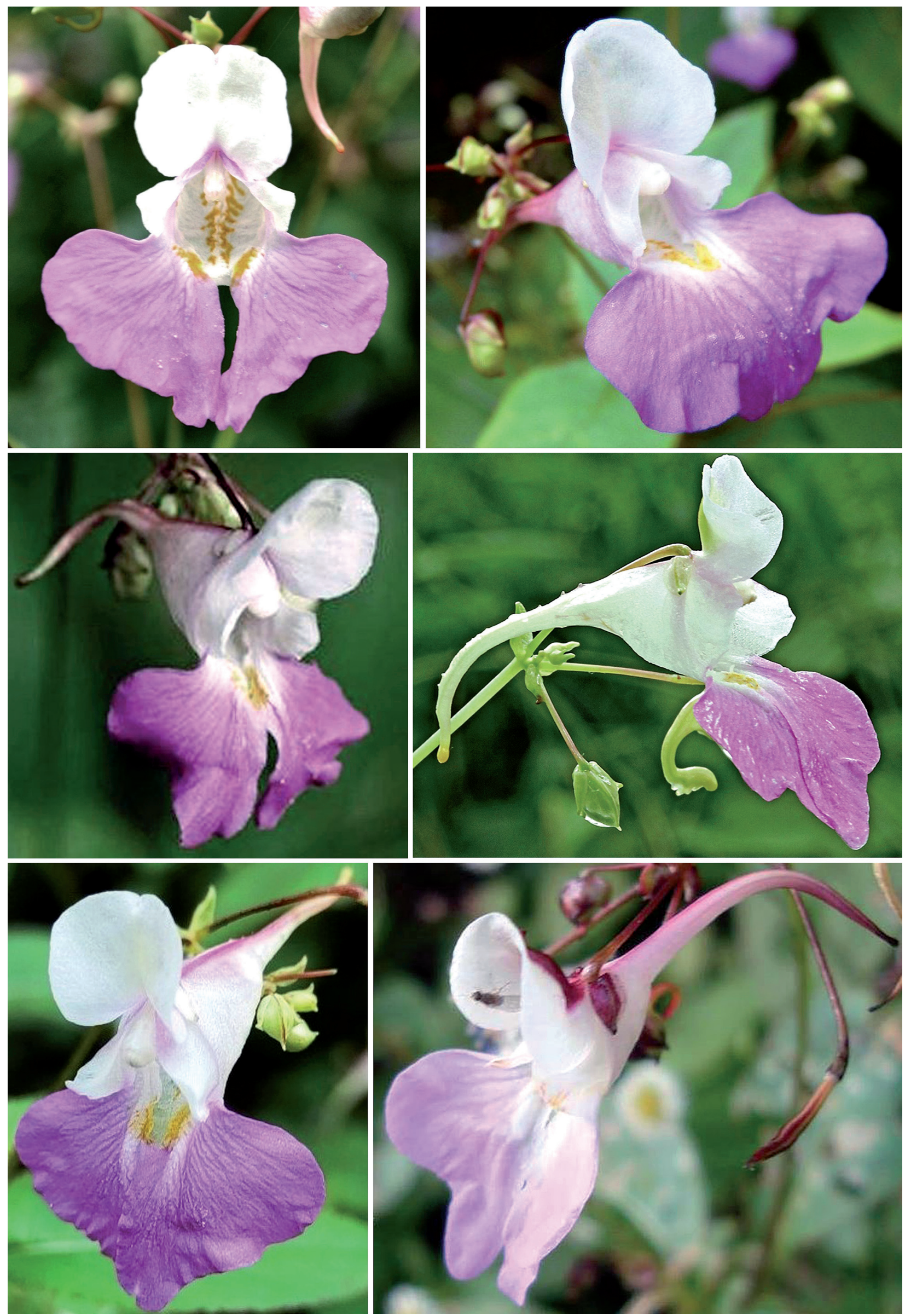

Fig. 4. Impatiens balfourii, variation in lower sepals with spur 
Garden, Edinburgh are extant at K (K000694735 and K000694736). The specimen K000694736 agrees better with the information given in the protologue, contains the pencil drawing of flower parts and the dissected flower parts pasted on the sheet by J. D. Hooker. It also contains the mentioning of flowering date and place of cultivation (Hort. Bot. Edinburgh) written by anonymous and the note written by J.D. Hooker "Seeds from Saharunpore". Therefore, the specimen K000694736, is designated here as the lectotype, as it agrees well with the protologue. Two more specimens of I. balfourii (K000694733 and K000694734) made from the plants that flowered at the Royal Botanic Gardens, Kew, in September 1894 and August 1898, are held at K. These two specimens are annotated by J.D. Hooker as "I. balfourii Hk. f.", but not mentioned in the protologue and, therefore, not considered here as original material.

This species shows variability in the size of capsule and lower sepal with spur (Fig. 4). Many variable forms of $I$. balfourii were seen in the field and during studies of herbarium specimens at different herbaria (especially at BSD, CAL, DD and E [E00753054 and E00848494]). I. flemingii comes within the variability range of $I$. balfourii.

5. Impatiens balfourii var. meeboldii (Hook. f.) R. Kr. Singh \& D. Borah, comb. et stat. nov.

I. meeboldii Hook. f. in Bull. Misc. Inform. Kew 1910: 291. 1910.

Type citation in the protologue: "KASHMIR. Gurais, 2440 m., Aug. 1905, A. Meebold, 2467". L e c t o ty pe (first-step designated by Y.J. Nasir, Fl. Pakistan 133: 11. 1980): Gurais, Kashmir, 2440 m, Meebold s.n. (K000694790 and K000694791); secondstep designated here: India, Jammu \& Kashmir, Gurais, $8000 \mathrm{ft}$., 30 August 1905, A.K. Meebold s.n. (lower side specimen of K000694790!); isolectotypes three upper specimens of K000694790!, K000694791!.

I. dorjeekhandui Chowlu, S.S. Dash \& Gogoi in Nelumbo 59: 141. 2017, syn. nov.

H o l o t y pe: India, Arunachal Pradesh, Tawang district, Zemithang, Gorsam, 1719 m, 16 September 2017, K. Chowlu \& S. S. Dash 40952 (CAL!).

Distribution: Endemic to India (Arunachal Pradesh, Himachal Pradesh, Jammu \& Kashmir and Uttarakhand).

N o t e s: For the name Impatiens meeboldii Hook. f., the lower side specimen of K000694790, is designated here as the second-step lectotype. I. meeboldii is very similar to $I$. balfourii in all respects, except the shape of capsule, therefore, treated here as a variety of $I$. balfourii. Capsule is linear in I. balfourii var. balfourii and clavate in var. meeboldii. The protologue and type specimens of $I$. dorjeekhandui perfectly match with var. meeboldii.
6. Impatiens bicolor Royle, Ill. Bot. Himal. Mts. 151, t. 28, f. 1.1835.

Type citation in the protologue: "Hab. Mussooree and Simla".

Le c t o ty pe (designated here): India, Northwest India, s.d., J.F. Royle s.n. (K000694726!).

I. amphorata Edgew. in Trans. Linn. Soc. London 20(1): 39. 1846.

Type citation in the protologue: "Hab. Himala, in sylvis, alt. ped. 5000-7000; vulgatissima. Simla, \& c".

Le c t o type (designated here): India, Himalaya, Himachal Pradesh, Simla, 7000-8000 ft., 1844, M.P. Edgeworth 332 (K000694728!).

I. duthiei Hook. f. in Rec. Bot. Surv. India 4: 11. 1905, syn. nov.

Type citation in the protologue: "This apparently distinct undescribed species from the Western Himalaya has been received by me from Mr. Duthie".

Lectotype (designated here): India, Western Himalaya, Uttarakhand, Kumaon, 1900, Duthie's collector (Inayat) s.n. (upper specimen of K000694732!); isolectotypes DD!, lower specimen of K000694732!.

I. edgeworthii var. toppinii Hook. f. ex Toppin in Bull. Misc. Inform. Kew 1920: 348. 1920, syn. nov.

Type citation in the protologue: "Chitral: Ziarat; 2300-2700 m., Aug. 1908, Toppin 605".

L e c t o type (designated here): Pakistan, Chitral, Ziarat, 7000-8000 ft., August 1908, S.M. Toppin 605 (larger left hand side specimen of K000694738!); isolectotype smaller right hand side specimen of K000694738!.

I. pallens Edgew. in Trans. Linn. Soc. London 20(1): 39. 1846.

Type citation in the protologue: " $H a b$. Himala, ad alt. ped. 3000-6000, ad ripas rivulorum Garhwal".

L e c t o ty pe (designated here): India, Himalaya, Uttarakhand, Garhwal, 4000-8000 ft., 1844, M.P. Edgeworth 334 (left hand side specimen of K000694729!); isolectotype right hand side specimen of K000694729!.

I. pseudobicolor Grey-Wilson in Fl. Iranica 143: 9. 1979, syn. nov.

H o l o ty pe: Pakistan, Hazara, Hill territory, 7500 ft., 18 September 1958, B.L. Burtt \& M.A. Kazmi 1253 (E00841614!).

I. umbrosa Edgew. in Trans. Linn. Soc. London 20(1): 39. 1846.

Type citation in the protologue: "Hab. Himala, ad alt. ped. 7000-8000 in sylvis. Simla".

Le ct otype (designated here): India, Himalaya, Himachal Pradesh, Kangra, 3000-8000 ft., 1844, M.P. Edgeworth 334 (larger left hand side specimen of K000694727!). 
I. nepalensis Hook. f. in Rec. Bot. Surv. India 4: 14, 20. 1905 \& Hooker's Icon. Pl. 30: t. 2961. 1911.

Type citation in the protologue: "Central Nepal".

L e c t o t y pe (designated here): Nepal, 1821, Wallich cat. no. 4729 (K001039776!).

D i stributi on: Nepal, Pakistan and India (Himachal Pradesh, Jammu \& Kashmir and Uttarakhand).

N o t e s : Royle $(1835$, l.c.) described Impatiens bicolor based on the specimens collected from Mussoorie (Uttarakhand) and Shimla (Himachal Pradesh). At present, only one original specimen (K000694726) is extant at $\mathrm{K}$ for the name I. bicolor Royle and is designated here as the lectotype.

In the protologue of I. amphorata, Edgeworth (1846, l.c.) mentioned the type information as "Hab. Himala, in sylvis, alt. ped. 5000-7000; vulgatissima. Simla, $\& \mathrm{c}$. This implies that he might have collected more than one specimen from Shimla and surrounding areas ranging from $5000-7000 \mathrm{ft}$. A single type specimen is now extant at K (K000694728) for the name I. amphorata Edgew. and is designated here as the lectotype, as it agrees well with the protologue. For the name I. duthiei Hook. f., the upper specimen of K000694732, is designated here as the lectotype. The larger left hand side specimen of K000694738, is designated here as the lectotype for the name I. edgeworthii var. toppinii Hook. f. ex Toppin. For the name I. pallens Edgew., the left hand side specimen of K000694729, is designated here as the lectotype. The larger left hand side specimen of K000694727 is designated here as the lectotype for the name I. umbrosa Edgew. The smaller right hand side specimen of K000694727 is not of I. umbrosa Edgew.

For the name I. nepalensis, Hooker (1905) gave meager description and the type information as "Central Nepal". Later in 1911, he provided detailed description and complete information about the type specimens. No herbarium specimen of Wallich cat. no. 4729 is extant at herbarium of the Linnean Society (LINN), but duplicate of the same is extant at K (K001039776) and is designated here as the lectotype. The other two specimens of Wallich cat. no. 4729 in the name I. longicornu Wall. at K are of I. sulcata Wall. (K001039777) and I. bicornuta Wall. (K001039778), but the description given in the protologue of I. longicornu by Wallich (1824) matches with I. leptoceras DC. I. duthiei, I. edgeworthii var. toppinii and I. pseudobicolor are variable forms of I. bicolor. These forms are found within the populations of I. bicolor at many localities in Himachal Pradesh, Jammu \& Kashmir and Uttarakhand.

7. Impatiens bicolor var. devendrae (Pusalkar) R. Kr. Singh \& D. Borah, comb. et stat. nov.

I. devendrae Pusalkar in Taiwania 55: 18. 2010.
H o lotype: India, Uttarakhand, Chamoli district, Nanda Devi Biosphere Reserve, Alaknanda valley, 2900-3100 m, 6 August 2008, P.K. Pusalkar 111017 (BSD!).

Distribution: Endemic to India (Himachal Pradesh and Uttarakhand).

$\mathrm{N}$ o t e s: Impatiens devendrae differs from I. bicolor only in colour of flowers, therefore is treated here as a variety. In I. bicolor var. bicolor, the colour of dorsal petal is pink, lateral united petals and lower sepal are yellow with pink-purplish streaks (Fig. 5). In var. devendrae, a dorsal petal is white-light pink, lateral united petals and lower sepal are white-light pink with or without reddish-purplish streaks (Fig. 5).

8. Impatiens bicornuta Wall. in Roxb., Fl. Ind. (Carey \& Wallich ed.) 2: 460. 1824.

Type citation in the protologue: "I found this on Chundrugiri and Sheopore in Nipal. I have also had it from more northern mountains, towards GosainThan".

L e c t o type (first-step designated by Grey-Wilson, Kew Bull. 44: 62. 1989): Nepal, Wallich 4765 (K, two specimens K001039849 and K001039850); second-step designated here: Nepal, Chandaghery (Chandragiri), June 1821, Wallich cat. no. 4765 (K001039849!).

Remaining syntypes: Nepal, 1821, Wallich cat. no. 4765 (BR0000006591472!, CAL!, K001039850!).

I. arunensis Grey-Wilson in Kew Bull. 44: 65. 1989, syn. nov.

Hol otype: Nepal, Arun Khola, Upper Kashwa Khola, above Hedangha, 2800 m, 8 September 1981, Grey-Wilson et al. 4376 (K000694616!).

I. harae H. Ohba \& S. Akiyama in J. Jap. Bot. 62: 368. 1987, syn. nov.

Hol otype: Nepal, Ramechhap district, Neju Choarma, 2 August 1985, H. Ohba et al. 8530680 (TI!). P a raty pe: Nepal, Ramechhap district, Choarma - Kyama, 3 August 1985, H. Ohba et al. 8530740 (TI!).

I. harae var. micrantha (H. Hara) H. Ohba \& S. Akiyama in J. Jap. Bot. 62: 369. 1987, syn. nov.

I. bicornuta var. micrantha H. Hara, Fl. E. Himalaya $3^{\text {rd }}$ Rep. 78. 1975.

H o l o ty p e: Nepal, Rasuwa district, Dunche-Trisuli Khola - Singum Gompa, 22 August 1972, H. Kannai, H. Hara \& H. Ohba 723214 (TI00013971!).

I. inayatii Hook. f. in Rec. Bot. Surv. India 4: 6, 10. 1904, syn. nov.

Type citation in the protologue: "Kumaon; Kali valley, Sosa forest, Inayat".

L e c t ot ype (designated here): India, Uttarakhand, Kumaon, Kali valley, Sosa forest, 8000-9000 ft., 17 September 1900, Inayat 23987 (K000694900!); isolectotype DD!. 
I. kaliensis Grey-Wilson in Kew Bull. 44: 65. 1989, syn. nov.

H o l o ty pe : India, Uttarakhand, Kumau (Kumaon), Pithoragarh district, Munshiyari (Munsiyari), 5 August 1900, Inayat 23958 (K000694656!).
I. pradhanii H. Hara in J. Jap. Bot. 40: 99. 1965. Hol otype: India, Sikkim, Lagyap, 13 September 1964, K.C. Pradhan \& H. Hara 6306729 (TI).

I. pyrorhiza Lidén \& Bharali in Nordic J. Bot. 35: 411. 2017, syn. nov.
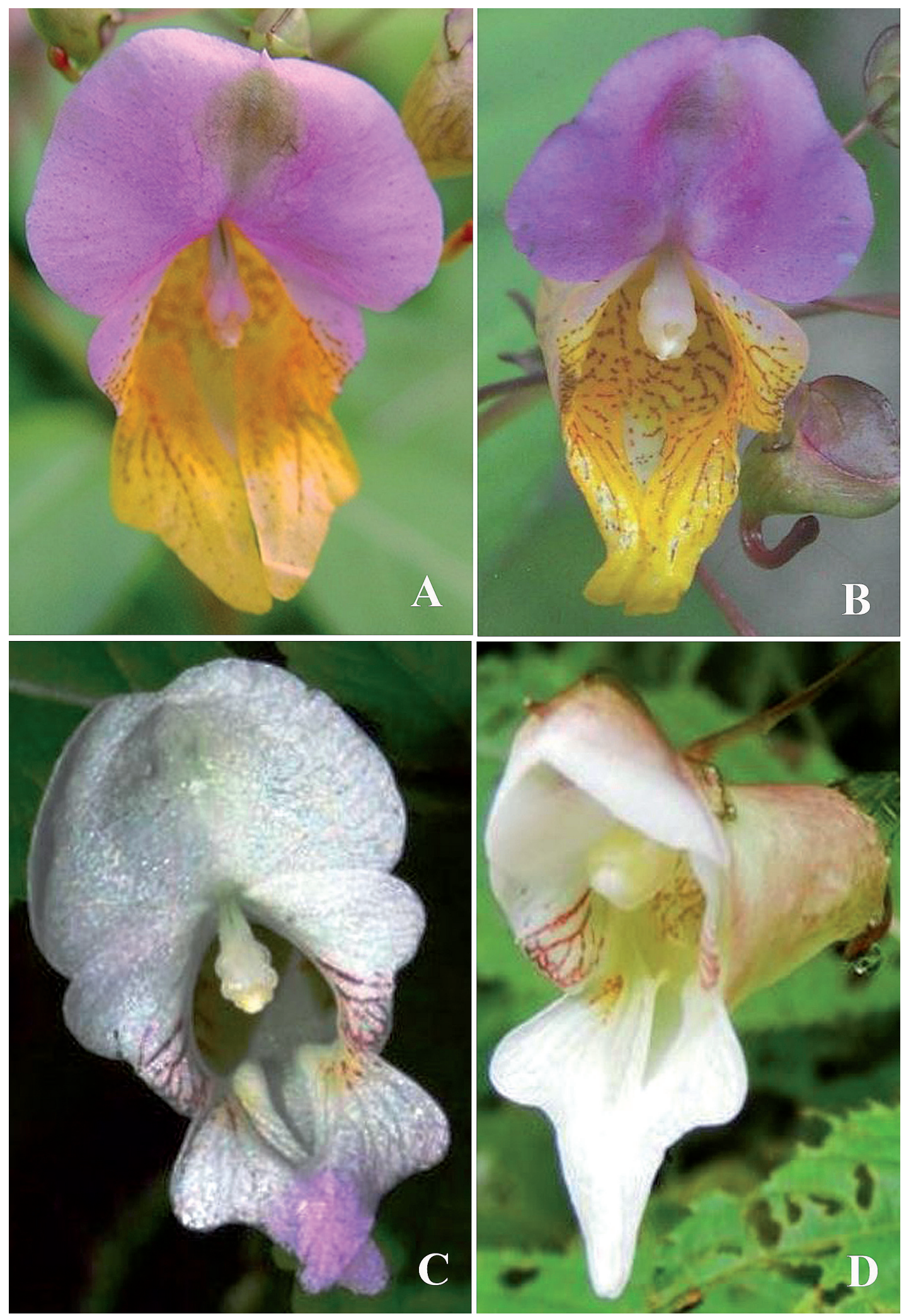

Fig. 5. Impatiens bicolor var. bicolor (A-B), I. bicolor var. devendrae (C-D) 
Hol otype: India, Arunachal Pradesh, West Kameng, Senge to Se La, shaded road bank, 3400 m, 7 October 2016, P. Bharali \& M. Lidén 2016-9 (CAL).
D istribution: Bhutan, China, Nepal and India (Arunachal Pradesh, Himachal Pradesh, Jammu \& Kashmir, Sikkim and Uttarakhand).

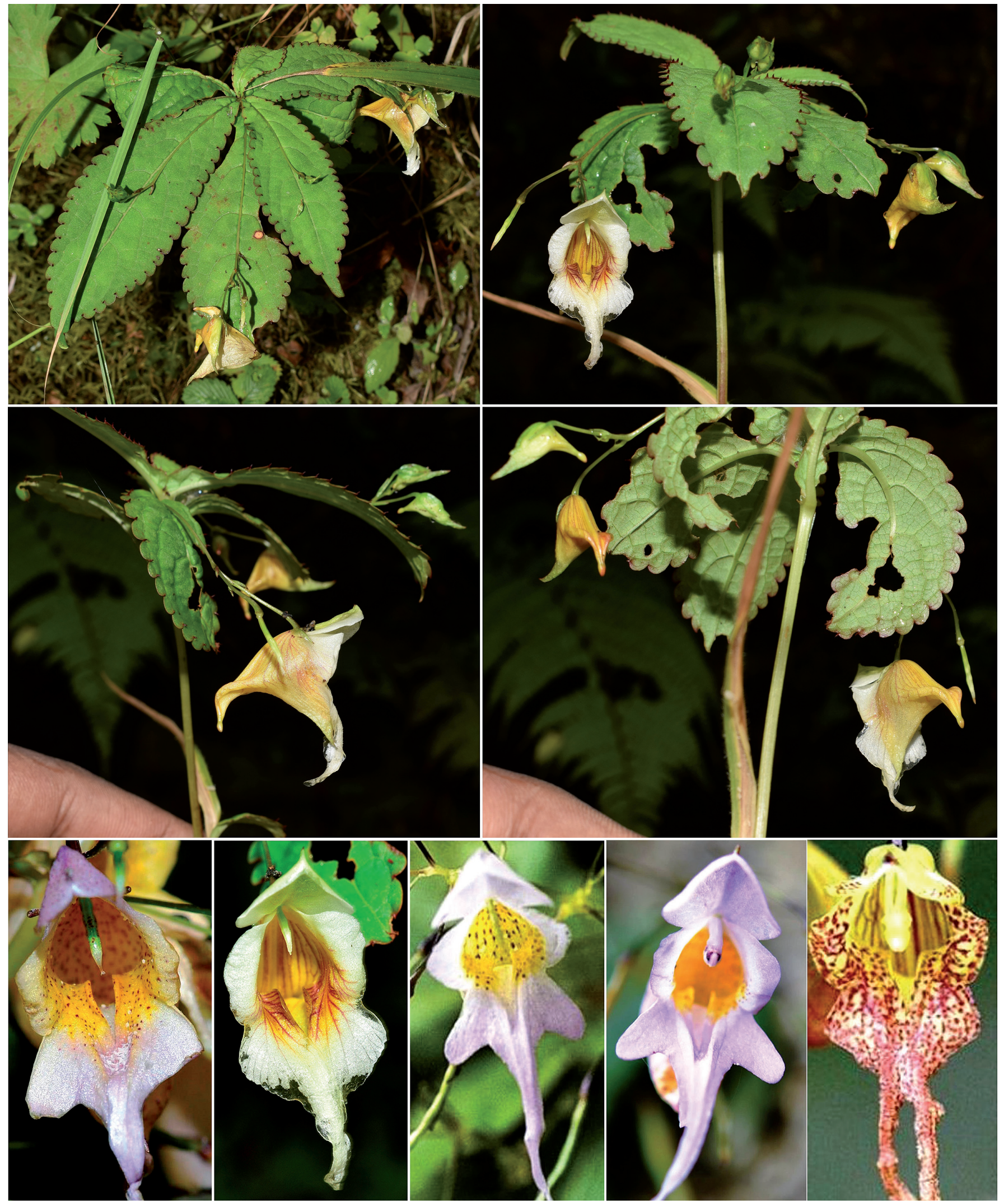

Fig. 6. Impatiens bicornuta, variation in flower colour 
Notes: Wallich (1824) described Impatiens bicornuta based on the specimens collected from three localities: Chandragiri, Shivapuri and Gosainthan of Nepal. Grey-Wilson in Kew Bull. 44: 62.1989 cited the type for I. bicornuta as "Type: Nepal, Wallich 4765: (holotype K-Wallich; isotype K)" and in doing so he did an inadvertent lectotypification for the name $I$. bicornuta Wall. However, he did not annotate or specify which particular herbarium sheet of Wallich cat. no. 4765 from Nepal at K-W is the holotype and which one is the isotype at $\mathrm{K}$, because two herbarium sheets of Wallich cat. no. 4765 exist at K-W (K001039849 and K001039850). As per Art. 9.17 of ICN (Turland et al., 2018), the Grey-Wilson's type citation must be accepted as the first-step lectotypification. The type citation of Grey-Wilson can be further narrowed to a single specimen by the second-step lectotypification. Therefore, from the two specimens of Wallich cat. no. 4765 at K-W, the better preserved specimen K001039849 is designated here as the second-step lectotype for the name $I$. bicornuta Wall. For the name I. inayatii Hook. f., the better preserved specimen K000694900 is selected here as the lectotype.

Detail ecological studies of I. bicornuta Wall. in the field, and also the examination of the herbarium specimens of I. bicornuta complex housed at different herbaria (BSD, CAL, DD, E, K, L, P and TI) showed that it is a polymorphic species. Many forms of this species can be seen in the field in different habitat, showing variation in the size of stem, leaves, petioles, inflorescences, bracts, peduncles, pedicels, flower parts and capsules. The colour of flowers also varies from white-lilac-pink-purple-yellow with or without reddish-purple-brown dots and strips (Fig. 6), but the shapes of inflorescence and flower (especially all sepals, petals and spur) remain the same. Earlier, some of the forms were described as new taxa, namely: I. arunensis, I. bicornuta var. micrantha, I. harae, I. inayatii, I. kaliensis and I. pyrorhiza. Delimitation of these forms at infraspecific level is difficult due to overlapping of morphological characters in size and colour. Therefore, these taxa are synonymized under I. bicornuta after the detailed study of type specimens, other herbarium specimens, and live plants in different types of habitat.

9. Impatiens citrina Hook. f. in Rec. Bot. Surv. India 4: 17, 22. 1905.

Type citation in the protologue: "Mishmi Hills".

L e c t o ty pe (designated by Ruchis. et al. in Blumea 63: 228. 2018): India, Arunachal Pradesh, Mishmi Hills, near waterfall, s.d., W. Griffith 1235 (K000694584!).

I. idumishmiensis Gogoi, W. Adamowski, Borah \& Chhetri in Gogoi et al., Balsams E. Himal. 100. 2018, syn. nov.
H o 1 o t y p e: India, Arunachal Pradesh, Lower Dibang valley district, Mayodia, 16 September 2012, R. Gogoi \& S. Borah 21861 (CAL).

I. lohitensis Gogoi \& Borah in Taiwania 58: 15. 2013, syn. nov.

H o $l$ o t y p e: India, Arunachal Pradesh, Lohit district, after Udayak pass, on the road to Tidding, $1000 \mathrm{~m}$, 27 May 2011, R. Gogoi 24533 (CAL!); isotypes ARUN!, ASSAM!.

P a r a ty pe: Arunachal Pradesh, Lohit district, after Udayak pass, on the road to Tidding, $1000 \mathrm{~m}, 3$ July 2012, R. Gogoi \& S. Borah 24602 (ARUN!).

I. pseudocitrina Hareesh, M. Sabu \& Gogoi in Phytotaxa 282: 231. 2016, syn. nov.

H o l o t y p e: India, Arunachal Pradesh, Anjaw district, Samdal, on the road from Hayuliang to Walong, 1000 m, 12 May 2016, V.S. Hareesh 143791 (CAL!); isotypes CAL!, CALI.

$P$ a r a t y p e: India, Arunachal Pradesh, Anjaw district, Samdal, 20 May 2011, R. Gogoi 24344 (CAL!).

I. zironiana Gogoi, Hareesh \& W. Adamowski in Webbia 72: 83. 2017, syn. nov.

H o l o t y p e: India. Arunachal Pradesh, Lower Subansiri district, Ziro, Pine Groove, 1560 m, 2 July 2013, R. Gogoi 30539 (CAL!); isotypes ASSAM!.

D istribution: Myanmar (Putao district, Kachin state) and India (District Anjaw, Changlang, Lohit, Lower Subansiri, Tirap and West Kameng of Arunachal Pradesh state).

Notes: After the detailed study of Impatiens citrina Hook. f. in Arunachal Pradesh, we found that I. idumishmiensis, I. lohitensis, I. pseudocitrina and I. zironiana are variable forms of I. citrina. These forms were seen within the populations of I. citrina in some areas of the districts: Anjaw, Changlang, Lohit, Lower Dibang valley, Lower Subansiri, Tirap and West Kameng of Arunachal Pradesh state (Fig. 7). Therefore, I. idumishmiensis, I. lohitensis, I. pseudocitrina and I. zironiana are treated here as synonym of I. citrina. We found this species in two new localities, not reported earlier - Lohit district, Kamlang Wildlife Sanctuary, Glow Lake, 23 August 2017, D. Borah 5190 and West Kameng district, Bomdila, near a seasonal stream, 23 September 2017, D. Borah 5893.

10. Impatiens cyclosepala Hook. f. ex W.W. Sm. in Notes Roy. Bot. Gard. Edinburgh 8: 338. 1915.

Type citation in the protologue: "Hook. f. nomen tantum in Herb. Kew. et Herb. Edin. Moist open situations in side valleys.... G. Forrest. No. 4271".

L e c t o t y pe (designated here): China, West Yunnan, side valleys on the eastern flank of the Tali Range, 80009000 ft., June 1906, G. Forrest 4271 (E00313641!); isolectotype K000694043!. 
Distribution: China (Northwest Yunnan) and India (Arunachal Pradesh).

N o te s: Smith $(1915$, l.c.) described Impatiens cyclosepala based on the collection of G. Forrest 4271 from West Yunnan, China, housed at the herbaria of Edinburgh and Kew. Two herbarium specimens of G. Forrest 4271 from West Yunnan, China, are extant, one each at E (E00313641) and K (K000694043). The better preserved specimen E00313641 is chosen here as the lectotype, as it agrees well with the protologue and also has dissected flower parts pasted on the sheet and pencil drawing of floral parts on the sheet by J.D. Hooker.

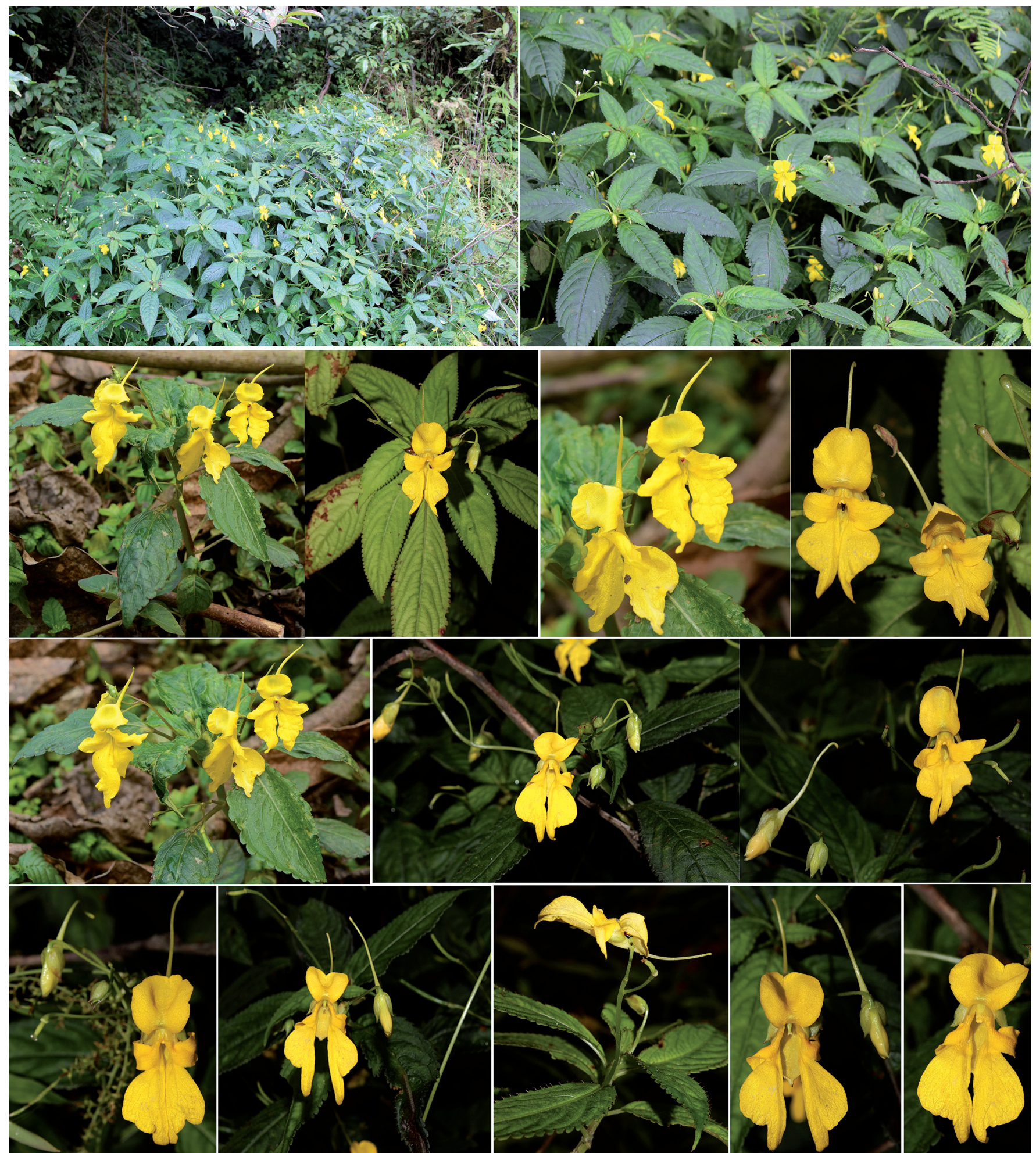

Fig. 7. Impatiens citrina, variation in flowers 
11. Impatiens decipiens Hook. f. in Rec. Bot. Surv. India 4: 17, 22. 1905.

Type citation in the protologue: "Sikkim and Chumbi, alt. 5,000-9,000 ft.?".

L e c t o t y p e (designated here): India, Sikkim, 1902, R. Pantling s.n. (upper right hand side specimen of K000694689!); isolectotype lower middle specimen of K000694689!.

Remaining syntypes: India, Sikkim, Teesta, 7 May, J.D. Hooker s.n. (upper left hand side specimen of K000694689!); India, Sikkim, Lamthang, September 1903, Prain's collector 15 (CAL!); India, Sikkim, 4000-7000 ft., s.d., Impatiens no. 99, J.D. Hooker s.n. (three upper right hand side specimens annotated by J.D. Hooker as "see decipiens" with barcode K000694931!, S11-12007!).

D i s tribution: Endemic to India (Sikkim and the Darjeeling district of West Bengal).

Notes: In the protologue of Impatiens decipiens, Hooker (1905) mentioned only information of locality - Sikkim and Chumbi, but did not provide the name of collectors, collection numbers, date of collections and name of herbarium where specimens was housed. Four original herbarium sheets were traced for the name $I$. decipiens Hook. f. (CAL, K000694931, K000694689 and S11-12007). The sheet K000694689 contains three specimens, the upper left hand side specimen of K000694689 is collected by J.D. Hooker from Teesta, Sikkim, and the remaining two collected by R. Pantling from Sikkim. The upper right hand side specimen of K000694689, collected by R. Pantling, is better preserved and is designated here as the lectotype, as it agrees well with the protologue.

12. Impatiens exilis Hook. f. in Rec. Bot. Surv. India 4: 13, 19. 1905.

Type citation in the protologue: "Sikkim, alt. 2,000-5,000 ft.".

L e c t o ty pe (designated here): India, West Bengal, Darjeeling, Pomong, 3000 ft., 23 August 1869, C.B. Clarke 869 b (K000694677!).

Remaining syntypes: India, West Bengal, Darjeeling, s.d., W. Griffith 1244 (three right hand side specimens of K000694676!, P04543279!); India, West Bengal, Darjeeling, 1901, R. Pantling s.n. (CAL!, single left hand side specimen of K000694676!).

D i s tributi on: Bhutan, Nepal and India (Sikkim, Darjeeling and Kalimpong districts of West Bengal).

Note s: While describing Impatiens exilis, Hooker (1905) mentioned only locality information as "Sikkim, alt. 2,000-5,000 ft.", but did not provide the name of collectors, collection numbers, date of collections and name of herbarium where specimens was housed. Four original herbarium sheets for the name I. exilis Hook. f. were traced (CAL, K000694676, K000694677 and
P04543279), annotated by J.D. Hooker as "I. exilis Hf". Of these, the best one K000694677 is designated here as the lectotype, as it agrees well with the protologue and also has drawing of floral parts on the sheet by J.D. Hooker and C.B. Clarke. After the independence of India, Darjeeling was merged with the state of West Bengal.

13. Impatiens falcifera Hook. f. in Bot. Mag. 129: t. 7923. 1903.

Type citation in the protologue: "Sikkim Himalaya, at elevations of eight to ten thousand feet". L e c totype (designated here): India, Sikkim, Lachung River, 8000-9000 ft., 2 October 1849, Impatiens no. 88, J.D. Hooker s.n. (right hand side specimen of $\mathrm{K} 000694740$ !); isolectotypes remaining specimens of K000694740!.

Remaining syntype: India, Sikkim, Lachen, 9000-11000 ft., 31 July 1849, Impatiens no. 88, J.D. Hooker s.n. (K000694739!).

Distribution: Bhutan, China, Nepal and India (Sikkim). N o t e s: Hooker (1903, l.c.) described Impatiens falcifera based on the specimens collected by him from Sikkim. Two original herbarium sheets for the name I. falcifera Hook. f. were traced at K (K000694739 and K000694740). The better preserved, right hand side specimen of K000694740, is designated here as the lectotype, as it agrees well with the protologue.

See the notes given under I. serrata Hook. f., regarding the gathering of Impatiens no. 88 of J.D. Hooker from Sikkim.

14. Impatiens gammiei Hook. f. in Rec. Bot. Surv. India 4: 16, 21. 1905.

Type citation in the protologue: "Sikkim, alt. 10,000 ft.".

N e ot y pe (designated here): India, West Bengal, Darjeeling, Sabarkum, 11000 ft., 1 October 1906, I.H. Burkill 27689 (K000694668!).

I. minimiflora Hook. f. in Rec. Bot. Surv. India 4: 16, 21. 1905.

Type citation in the protologue: "Sikkim, alt. 10,000 ft.".

L e c t o t y p e (designated here): India, Sikkim, Yakla, 11000 ft., 15 October 1869, C.B. Clarke 9874B (upper side specimen of K000694788!); isolectotypes CAL!, lower side specimen of K000694788!.

D istribution: Endemic to India (Arunachal Pradesh, Sikkim and West Bengal).

Notes: In the protologue of Impatiens gammiei, Hooker (1905) cited only locality, but did not provide the name of collector/s, collection number/s, date of collection/s and name of herbarium where specimen/s was/were housed. Hooker's types are known to be mainly at $\mathrm{K}$, some Indian materials at BM, BR, CAL, 
E, G, L, M, MANCH, MH, NY and P, but no original material collected from Sikkim before 1905 was found there. Thus, the specimen K000694668 collected by I.H. Burkill from Darjeeling in October 1906, is chosen here as the neotype for the name I. gammiei Hook. f. The specimen is well preserved, has mature leaves, well developed flowers, capsules and drawing of floral parts on the sheet by J.D. Hooker.

For the name I. minimiflora Hook. f., one original herbarium sheet is extant at $\mathrm{K}$ (K000694788). The upper side specimen of K000694788 is designated here as the lectotype.

15. Impatiens hobsonii Hook. f. in Rec. Bot. Surv. India 4: 15, 20. 1905.

Type citation in the protologue: "Sikkim, Yatung, alt?".

L e c t o ty pe (designated here): India, Sikkim, Lachen valley, Yatung, $27^{\circ} 51^{\prime} \mathrm{N}$ and $88^{\circ} 35^{\prime} \mathrm{E}, 1897$, H.E. Hobson s.n. (K000694824!).

D is tribution: Nepal and India (Sikkim).

Notes: In the protologue of Impatiens hobsonii, Hooker (1905) mentioned only precise locality, but did not provide the name of collector/s, collection number/s, date of collection/s and name of herbarium where specimen/s was/were housed. At present, only one original specimen for the name $I$. hobsonii Hook. f. is extant at $\mathrm{K}(\mathrm{K} 000694824)$ and is chosen here as the lectotype as it agrees well with the protologue.

16. Impatiens infundibularis Hook. $f$. in Rec. Bot. Surv. India 4: 13, 19. 1905.

Type citation in the protologue: "Sikkim, alt. 1,000-4,000 ft.".

L e c t o ty p e (designated here): India, Sikkim, s.d., 2000-5000 ft., J.D. Hooker s.n. (left hand side specimen of K000694661!); isolectotypes CAL!, right hand side specimen of K000694661!.

Re maining syntype: India, Sikkim, Richi La, September 1903, Prain's collector 78 (CAL!).

D i s t r i b u t i o n: Bhutan and India (Sikkim and hilly areas of West Bengal adjacent to Sikkim and Bhutan). N o t e s: For the name Impatiens infundibularis Hook. $\mathrm{f}$., three original herbarium sheets were traced, one at $\mathrm{K}$ (K000694661) and two at CAL. The left hand side specimen of K000694661 is chosen here as the lectotype.

17. Impatiens khasiana Hook. f. in Rec. Bot. Surv. India 4: 27, 33. 1905.

I. bella var. major Hook. f., Fl. Brit. India 1: 459. 1874.

Type citation in the protologue: "Khasia, alt. 5-6000 ft.".

L e c t o ty pe (designated by Odyuo et al. in Telopea 18: 85. 2015): India, Meghalaya, Khasia, 5000-6000 ft, s.d., J.D. Hooker \& T. Thomson s.n. (K000694831!); isolectotypes K000694829!, L0389061!, L0389062!, P04543343!.

Re maining syntype: India, Khasia, Bogapani (in Tinsukia District, Assam), 29 June 1841, J.D. Hooker \& T. Thomson 1376 (K000694832!).

I. kamtilongensis Toppin in Bull. Misc. Inform. Kew 1920: 356. 1920, syn. nov.

Type citation in the protologue: "Kamti Long Hills. Kumtat; in wet, shady places at $500 \mathrm{~m}$., Sinar at 650 m., Dec., 1911. Toppin 4275".

Lectotype (designated by Ruchis. et al. in Blumea 63: 253. 2018): Myanmar, Kachin Hills, Kumtat at $1600 \mathrm{ft}$., Sinar at 1950 ft., s.d., S.M. Toppin 4275 (K000694653!); isolectotypes K000694654!, K000694655!.

I. pritchardii Toppin in Bull. Misc. Inform. Kew 1920: 359. 1920.

Type citation in the protologue: "Kachin Hills, Wasi, at 170 m., in damp shady places, 12.12.1911. Toppin 4093".

L e c t o ty pe (designated by Ruchis. et al. in Blumea 63: 252. 2018): Myanmar, Wasi, 500 ft., 12 December 1911, S.M. Toppin 4093 (K000694828!).

I. toppinii Dunn in Bull. Misc. Inform. Kew 1920: 353. 1920, syn. nov.

I. khasiana var. toppinii (Dunn) Ruchis. \& Suksathan. in Blumea 63: 253. 2018.

Type citation in the protologue: "Kachin Hills. Sinlum; at 1500-1800 m., June and July, 1911, Toppin 2781".

Le ctotype (designated by Borah et al. in Telopea 18: 34. 2015): Myanmar, Sinlum, 4500-5500 ft., s.d., S.M. Toppin 2781 (K000694915!); isolectotypes K000694913!, K000694914!, K000694916!, K000694917!, K000694918!, K000694919!.

D istribution: Myanmar and India (Assam, Meghalaya and Arunachal Pradesh).

N ote s: Study of Impatiens khasiana in different environmental conditions and habitats revealed that this taxon shows variation in the size of leaves, stem, peduncle, pedicels and degree of indumentum (Fig. 8). Ruchisansakun et al. (2018) treated I. toppinii as a variety of I. khasiana based on marginal characters, the size of stem and leaves, and erect and decumbent stem. However, these characters are integrated with the populations of I. khasiana at some localities. After examination of herbarium specimens (including a type specimen) of I. kamtilongensis and I. toppinii and live plants, it was found that these taxa are conspecific with I. khasiana.

18. Impatiens kingii Hook. f. in Rec. Bot. Surv. India 4: 14, 19. 1905 \& Hooker's Icon. Pl. 30: t. 2960. 1911. Type citation in the protologue: "Sikkim, alt?". 
L e c t o t y pe (designated here): India, Sikkim, Bloktan below Jongri (Dzongri), July 1887, King's collector 4474 (K000694826!); isolectotype CAL!.

Re maining syntypes: India, Sikkim, Jongri (Dzongri), 1887, King 's collector 4474 (K000694825!); India, Sikkim, Ja-ne-doo, 7 August 1887, G. King 4474 ( CAL!, K000694827!).

D i s tributi on: Bhutan and India (Sikkim).

Notes: For the name Impatiens kingii, Hooker (1905) provided meager description and the type infor- mation as "Sikkim, alt ?". Later in 1911, he provided detailed description and complete information about the type specimens. Five specimens belonging to the original material were traced, two at CAL and three at K (K000694825, K000694826 and K000694827). Of these, the better preserved specimen K000694826, is designated here as the lectotype, as it agrees well with the protologue. It also contains the pencil drawing of flower parts and the dissected flower parts pasted on the sheet by J.D. Hooker.

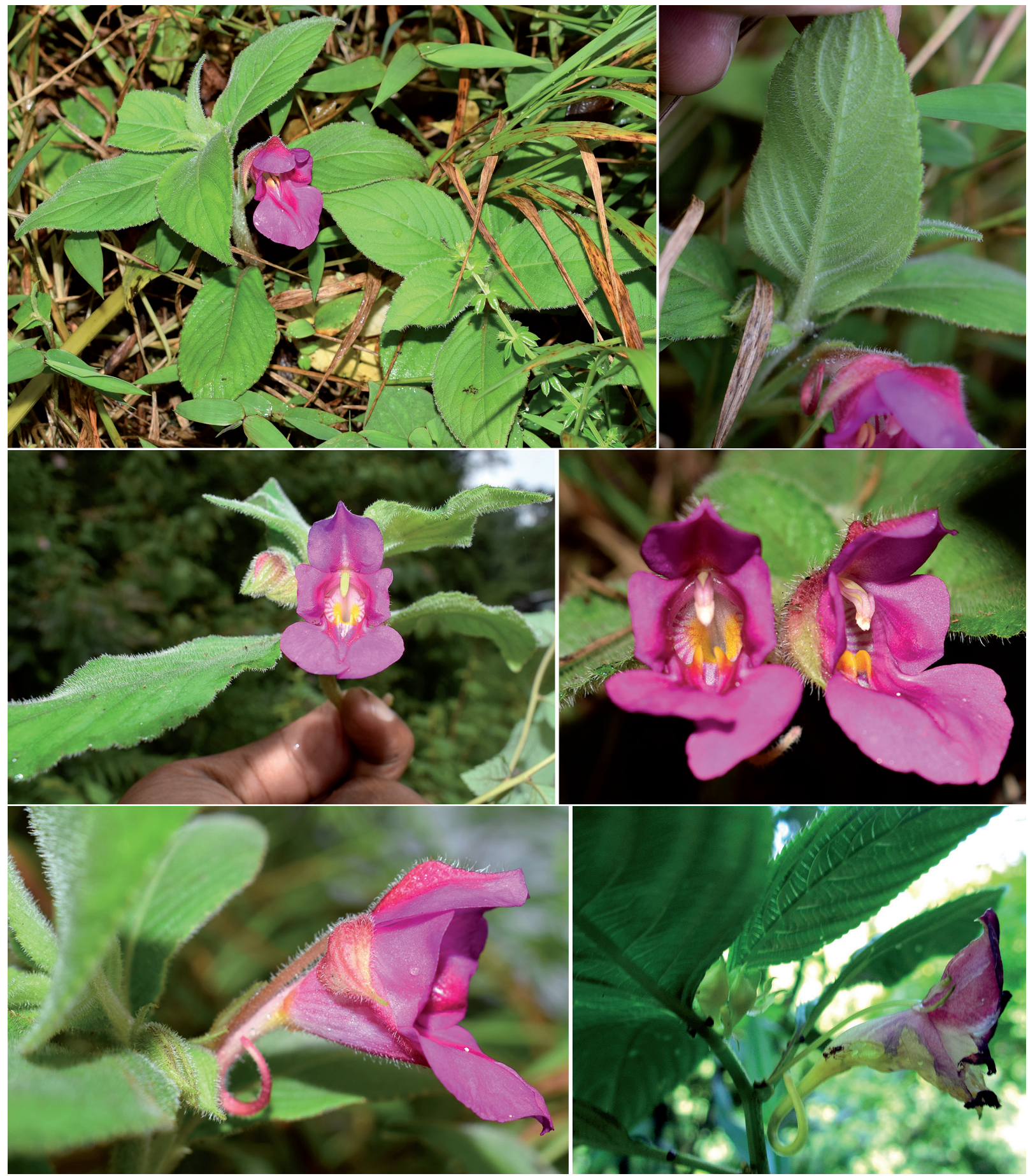

Fig. 8. Impatiens khasiana, variation in the degree of indumentum on plant parts 
19. Impatiens latiflora Hook. f. \& Thomson in J. Proc. Linn. Soc., Bot. 4: 139. 1859.

Type citation in the protologue: "Hab. Umbrosis subtropicis montibus Khasia ad Nunklow, alt. 3000-4000 ped. Lobb, J. H. \& T. T. et ? Himalaya orientali tropica Sikkim, alt. 2000-4000 ped., J. H. (fl. Oct.)".

L e c t o t y p e (designated here): India, Khasia, Munklow, 3000-4000 ft., 18 October 1859, J.D. Hooker \& T. Thomson s.n. (upper left hand side specimen of
K000694816!); isolectotype - lower right hand side specimen of K000694816!.

Remaining syntypes: India, Khasia, Munklow, 3000-4000 ft., s.d., J.D. Hooker \& T. Thomson s.n. (B100365143!, G00237317!, G00237318!, K000694818!, L0389069!, L0389070!, M0211760!, MH64241!, MPU019003!, NY00006755!, P04543228!, P04543229!, S-G3353!, U1149136!); India, Khasia, below Munklow, 3000-4000 ft., 11 July 1950, J.D. Hooker \& T. Thomson 1599 (K000694817!,
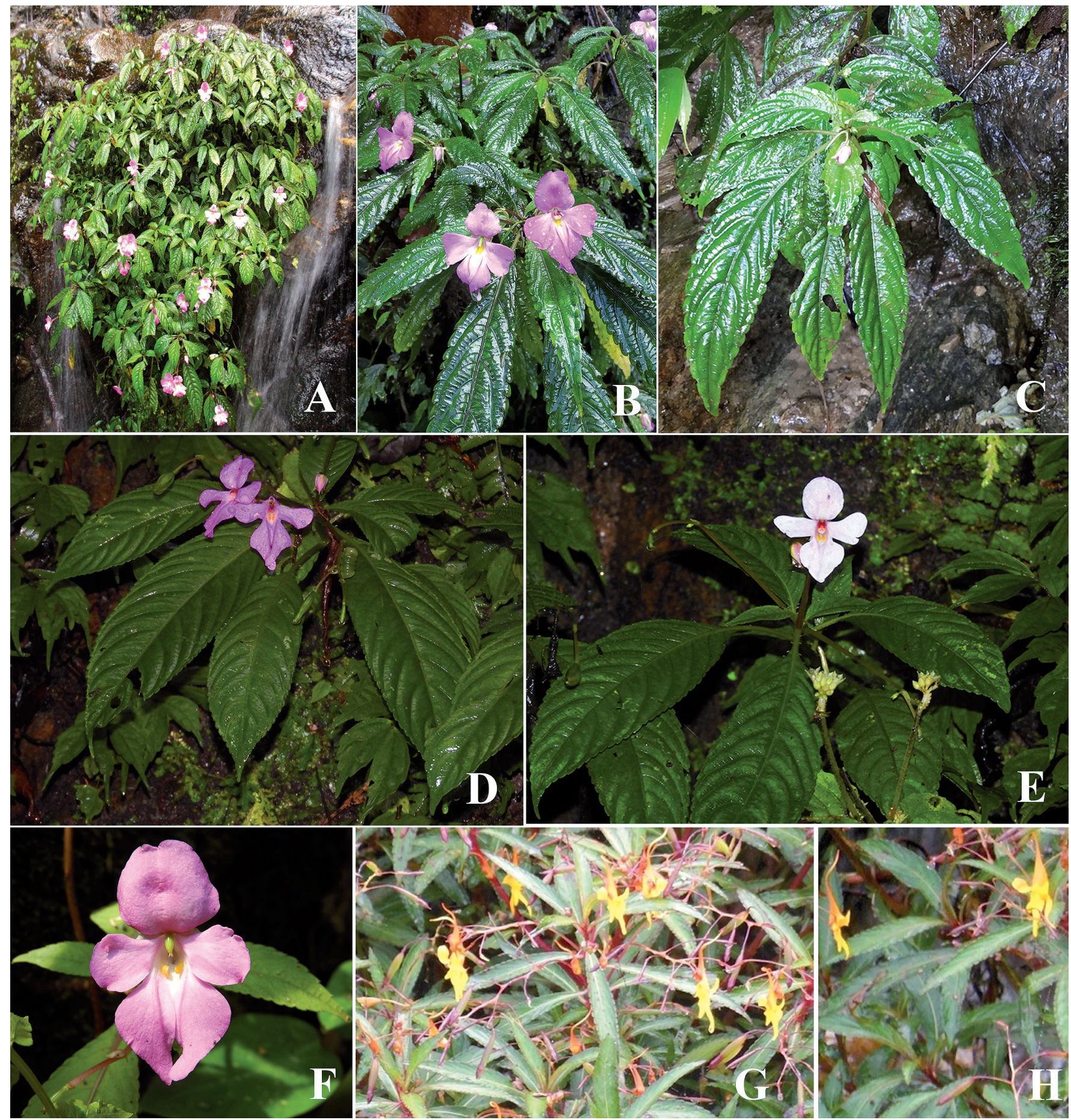

Fig. 9. Variation in flowers of Impatiens latiflora (A-F) and I. leptoceras (G-H) 
K000694819!); India, Khasia hills, 3500 ft., s.d., T. Lobb s.n. (K000694820!): India, Dapla, s.d., Booth s.n. (K000694821!).

D i s t r i b u t i o n : Bhutan and India (northeast Indian states).

N o t e s: As per type citation in the protologue of Impatiens latiflora Hook. f. \& Thomson, eighteen herbarium specimens were traced (B100365143, G00237317, G00237318, K000694816, K000694817, K000694818, K000694819, K000694820, K000694821, L0389069, L0389070, M0211760, MPU019003, NY00006755, P04543228, P04543229, S-G3353 and U1149136). Of these, the best preserved upper left hand side specimen of K000694816 is designated here as the lectotype, as it agrees well with the protologue and also has dissected flower parts pasted on the sheet by J.D. Hooker. In this species, variation in flower colour (white-pink-purple) and the shape of basal lobes of lateral united petals is observed in the field (Fig. 9).

20. Impatiens leptoceras DC., Prodr. 1: 688. 1824.

Type citation in the protologue: "In Napaulia, Wallich".

L e c t o t y p e (designated here): Nepal, 1819, Wallich s.n. (G00218028!).

Remaining syntypes: Nepal, 1821, (Wallich cat. no. 4770) Wallich s.n. (G00218029!, K001039862!, K001039864!, lower specimen of S11-11891!).

I. angustiflora Hook. f., Fl. Brit. India 1: 480. 1875, syn. nov.

Type citation in the protologue: "KHASIA MTS., alt. 5-7000 ft., Lobb, \& c.; BHOTAN, Griffith".

L e c t o t y pe (designated by Gogoi et al. in Nelumbo 62: 156. 2020): India, Khasia, s.d., T. Lobb s.n. (left hand side specimen of K000694623!).

Re maining syntypes: India, Khasia, $6000 \mathrm{ft}$., s.d., Impatiens no. 55, J.D. Hooker \& T. Thomson s.n. (CAL0000005176!, middle and right hand side specimens of K000694623!, P04543415!.

I. tongbiguanensis S. Akiyama \& H. Ohba in J. Jap. Bot. 70: 102, t. 5. 1995, syn. nov.

Hol otype: China, Yingjiang, Tongbiguan, 10001400 m, 1 October 1993, Cheng et al. 27 (TI).

D i stributi on: China, Nepal and India (northeast Indian states).

N o t e s: Two syntypes specimens for the name Impatiens leptoceras DC. are extant at G (G00218028 and G00218029). The best one, G00218028, is designated here as the lectotype.

The study of herbarium specimens and literature, showed no difference between I. angustiflora, I. tongbiguanensis and I. leptoceras (Fig. 9).
21. Impatiens occultans Hook. f. in Rec. Bot. Surv. India 4: 17, 22. 1905.

Type citation in the protologue: "Sikkim, alt. 12,000-13,000 ft".

L e c t o ty pe (designated here): India, Sikkim, Tankra Mt., 13500 ft., 2 August 1891, G.A. Gammie 414 (middle specimen of K000694783!); isolectotypes - right and left hand side specimens of K000694783!.

Remaining syntypes: India, Sikkim, August 1888, King's collector s.n. (CAL!); India, Sikkim, s.d., King's collector s.n. (CAL!).

D i stribution: China, Nepal and India (Sikkim). Notes: In the protologue of Impatiens occultans, Hooker (1905) cited the type locality with altitudinal range, but did not provide the name of collector/s, collection number/s, date of collection/s and name of herbarium where specimen/s was/were housed. Three original herbarium sheets were traced for the name $I . o c$ cultans Hook. f. The middle specimen of K000694783, is chosen here as the lectotype, as it agrees well with the protologue.

22. Impatiens porrecta Wall. ex Hook. f. \& Thomson in J. Proc. Linn. Soc., Bot. 4: 138. 1859.

Type citation in the protologue: "I. porrecta (Wall. Cat. 7275!). Hab. Paludibus temperatis montibus Khasiae! Wallich, prope Kalapane, alt. 50006000 ped., J. H. \& T. T. (fl. Aug.). (v.v.)".

L e c t o t y p e (designated by Ruchis. et al. in Blumea 63: 251. 2018): India, Mount. Sylhet, s.d., Wallich cat. no. 7275, W. Gomez s.n. (K001127061!).

Remaining syntypes: India, Khasia, $4000 \mathrm{ft}$., s.d., Impatiens no. 91, J.D. Hooker \& T. Thomson s.n. (L0249362!, P04543679!).

I. andersonii Hook. f. in Rec. Bot. Surv. India 4: 27, 33. 1905, syn. nov.

Type citation in the protologue: "Shan States; Hoetone".

L e c t o t y p e (designated by Ruchis. et al. in Blumea 63: 254. 2018): Myanmar, Hoetone, 1 September 1868 , D.J. Anderson s.n. (K000694627!).

I. bella Hook. f. \& Thomson in J. Proc. Linn. Soc., Bot. 4: 138. 1859.

Type citation in the protologue: "Hab. Paludibus temperatis mont. Khasiae! Griffith, Lobb; prope Kalapane alt. 5000 ped., J. H. \& T. T. (fl. Aug.). (v.v.)".

L e c t o t y pe (designated by Ruchis. et al. in Blumea 63: 251. 2018): India, Khasia, s.d., W. Griffith s.n. (K000694775!); isolectotype NY04028831!.

Re maining syntypes: India, Khasia, s.d., Impatiens no. 92, J.D. Hooker \& T. Thomson s.n. (L0388756!, MH64239!, NY04028832!, U1149125!); India, Khasia, s.d., T. Lobb s.n. (K000608266!); India, Assam, Kalapane (Kalapani), 4000-5000 ft., 6 August 
1850, Impatiens no. 92, J.D. Hooker \& T. Thomson 2029 (K000608265!, K000608267!); India, East Bengal (Khasia), s.d., W. Griffith 1231 (L0388757!).

I. garrettii Craib in Bull. Misc. Inform. Kew 1926: 160. 1926, syn. nov.

Type citation in the protologue: "Doi Angka, 1300-1675 m., Garrett 94”.
L e c t o t y pe (designated by Ruchis. et al. in Blumea 63: 254. 2018): Thailand, Doi Angka 1300-1678 m, 26-28 October 1910, H.B.G. Garrett 94 (K000675566!); isolectotypes BKF005985!, BM000797133!, E00753953!, K000675565!.

I. marianae Rchb. f. ex Hook. f. in Rec. Bot. Surv. India 4: 27, 33. 1905, syn. nov.
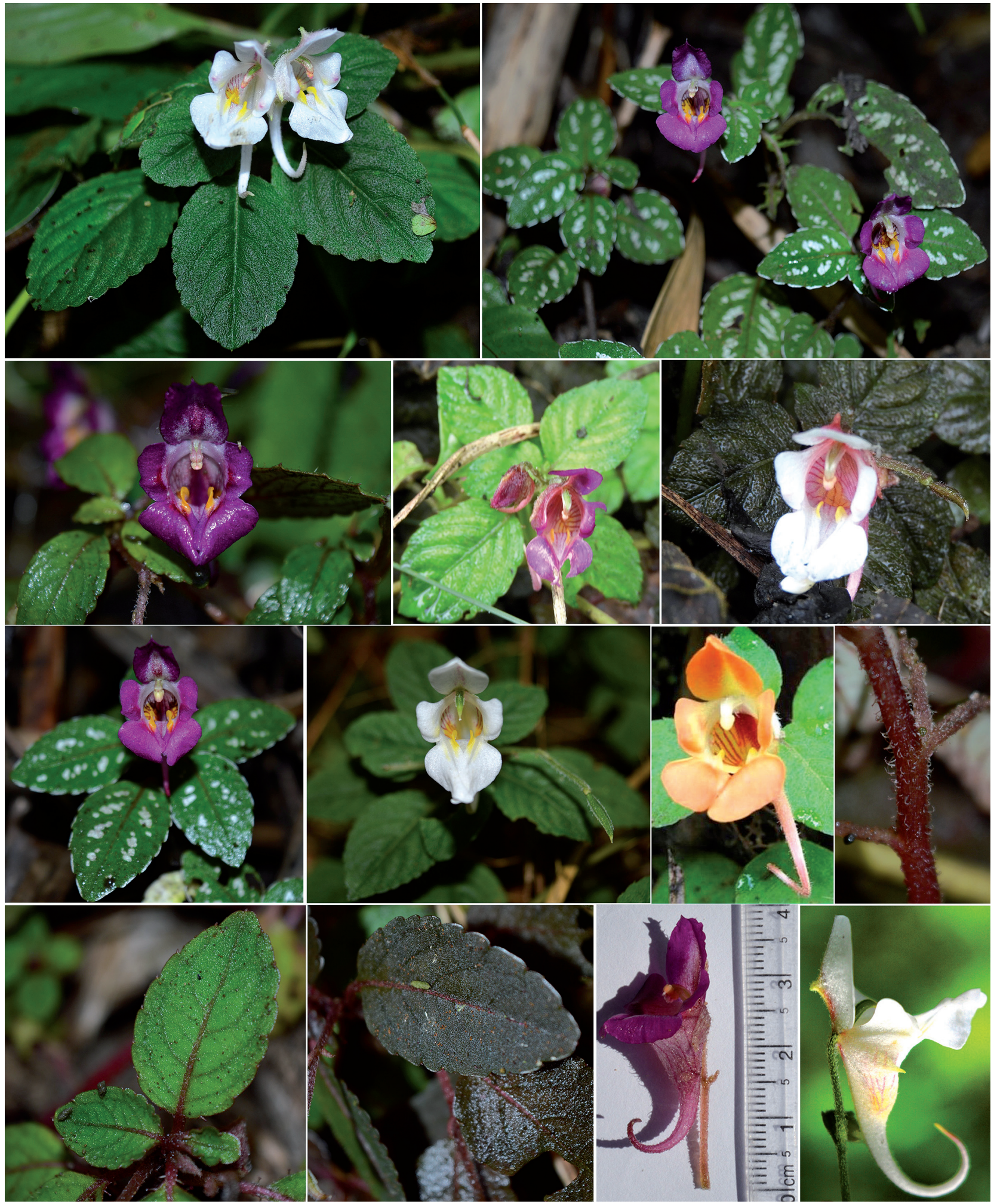

Fig. 10. Impatiens porrecta, variation in leaves and flower colour 
Type citation in the protologue: "Assam".

L e c t o t y pe (designated here): India, Assam, upper Dehing forests, Lakhimpur district, July 1879, G. Mann 488 (K000694794!).
Remaining syntypes: India, Assam, upper Dehing forests, June 1887, G. Mann s.n. (K000694792!); India, Khasi hills, Shillong, cultivated, $5000 \mathrm{ft}$., September 1886, G. Mann s.n. (K000694793!).
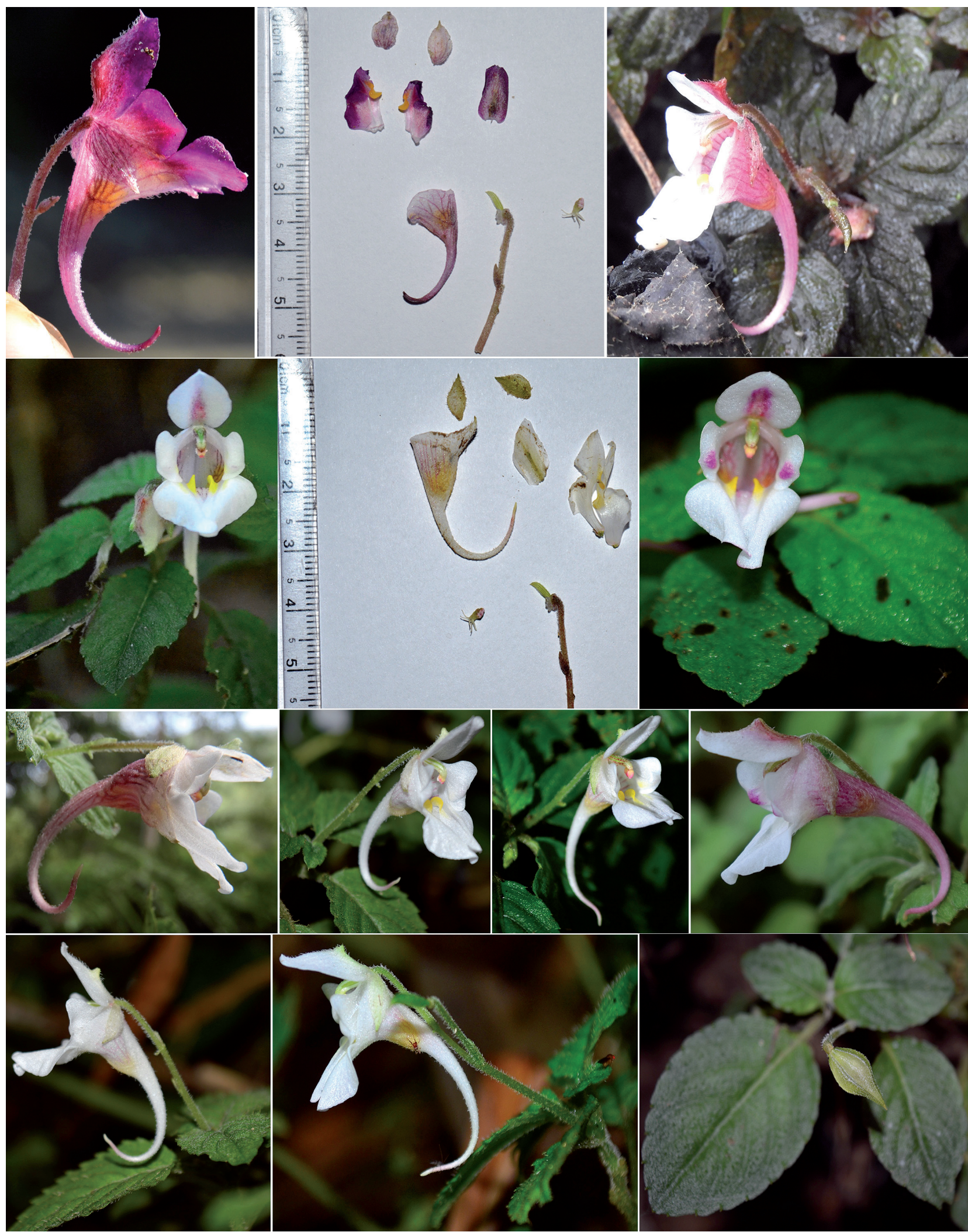

Fig. 11. Variation in flowers of Impatiens porrecta 
I. nicolsoniana Gogoi \& Arisdason in Phytotaxa 273: 145. 2016, syn. nov.

I. mannii C.B. Clarke ex Hook. f. in Rec. Bot. Surv. India 4: 27, 33. 1905, nom. illeg., non Hook. f., 1861. Type citation in the protologue: "Assam".

H o l o type: India, Assam, Lakhimpur, Makum forest, 1889, G. Mann S.n. (K000694773!).

I. putaoensis Y.H. Tan, S.S. Zhou \& B. Yang in Phytotaxa 321: 107. 2017, syn. nov.

Hol ot ype: Myanmar, Kachin state, Putao, Ghatu village, 590 m, 25 November 2014, Myanmar Exped.105 (HITBC).

I. striolata Hook. f. in Rec. Bot. Surv. India 4: 28, 33. 1905, syn. nov.

Type citation in the protologue: "Khasia Hills, alt. 1,000-5,000 ft.".

L e c t o ty pe (designated by Ruchis. et al. in Blumea 63: 249. 2018): India, Khasia, above Kalapani (presently in Assam) 5000 ft., s.d., Impatiens no. 91, J.D. Hooker \& T. Thomson s.n. (K000694624!).

Re maining syntype: India, Khasia, Kalapani, 4000-6000 ft., 5 August 1850, J.D. Hooker \& T. Thomson 2026 (K000694625!).

Dis tribution: Laos, Myanmar, Nepal, Thailand and India (northeast Indian states)

Notes: Three original specimens were traced for the name Impatiens marianae Rchb. f. ex Hook. f. (K000694792, K000694793 and K000694794). The specimen K000694794 contains the pencil drawing of flower parts and the dissected flower parts pasted on the sheet by J.D. Hooker and is designated here as the lectotype.

Thorough ecological studies of I. porrecta in different habitats showed that it is a polymorphic species and forms a complex that shows variation in the size of stem, leaves, petiole, peduncle and flower parts. It also shows variation in the covering of hairs (indumentum) on stem, leaves and flower, and colour of flowers from white to pink-rosy-yellow (Figs. 10-11). In some places we found variegated and non-variegated leaves within the same population (Fig. 10), this form was earlier known as I. marianae. Similarly, some of the forms based on quantitative characters are known by different names I. andersonii, I. bella, I. garrettii, I. nicolsoniana, I. putaoensis and I. striolata. These names were originally segregated primarily by differences in colour of flowers, covering of hairs and other quantitative characters, but after critical examination of live specimens in the field and herbarium specimens (including types), it was found that these characters were inconsistent. These characters were also found to be variable over time and space within populations of living plants. The flowering and fruiting times, distribution patterns and habitat preferences of these taxa were found to overlap. It is even difficult to segregate these names at infraspecific level due to overlapping of taxonomical characters.

In 1905, J.D. Hooker described I. striolata from the syntype specimens of I. porrecta Wall. ex Hook. f. \& Thomson housed at K (India, Khasia, Impatiens no. 91, J.D. Hooker \& T. Thomson).

23. Impatiens pulchra Hook. f. \& Thomson in J. Proc. Linn. Soc., Bot. 4: 139. 1859.

Type citation in the protologue: "Hab. Umbrosis montibus Khasia regione temperata et subtropica alt. 5000 ped.! J. H. \& T. T.”.

L e c t o t y pe (designated by Ruchis. et al. in Blumea 63: 256. 2018): India, Khasia, Pomrang, 5000 ft., 16 September 1950, J.D. Hooker \& T. Thomson 2281 (K000694754!); isolectotype K000694753!.

Remaining syntypes: India, Khasia, $5000 \mathrm{ft}$., s.d., J.D. Hooker \& T. Thomson s.n. (B100365132!, C10008239!, G00237316!, K000694755!, L0389592!, M0211744!, MH64242!, NY00006752!, P04543743!, P04543744!, P04543746!, S-G-3355!, U1149151!).

I. pulchra var. $\beta$ Hook. f. \& Thomson in J. Proc. Linn. Soc., Bot. 4: 139. 1859.

Type citation in the protologue: "Nepalia maxime orientali, alt. 4000-5000 ped.! J. H. (fl. Sept.-Nov.) (v.v.)".

L e c t o t y pe (designated by Ruchis. et al. in Blumea 63: 257. 2018): Nepal, Moyong valley, 4000-5000 ft., October 1831, J.D. Hooker s.n. (K000694757!); isolectotypes K000694758!, L0389591!, P04023256!.

I. annulifera Hook. f. in Rec. Bot. Surv. India 4: 27, 33. 1905.

Type citation in the protologue: "Naga and Manipur Hills, alt. 3,000-5,500 ft.

Le c to type (designated by Ruchis. et al. in Blumea 63: 257. 2018): India, Manipur, Myring Naga hills, 5000 ft., December 1907, A. Meebold 6714 (K000694759!).

R e maining syntype: Nagaland, Kohima, 4000 ft, April 1896, Dr. King's collector 253 (K000694760!).

I. burmanica Hook. f. in Rec. Bot. Surv. India 4: 27, 33. 1905, syn. nov.

I. pulchra var. burmanica (Hook. f.) Ruchis. \& Suksathan. in Blumea 63: 257. 2018

Type citation in the protologue: "Upper Burma, Bhamo and Kachin Hills".

L e c t o t y pe (designated by Ruchis. et al. in Blumea 63: 257. 2018): Myanmar, Bhamo, June 1892, A. Huk s.n. (K000694719!).

Remaining syntypes: Myanmar, Kachin hills, 1897, S. Mokim s.n. (CAL!, K000694720!).

I. cuspidifera Hook. f. in Rec. Bot. Surv. India 4: 27, 33. 1905, syn. nov. 
Type citation in the protologue: "Naga Hills, alt. 6,000 ft.".

L e c t o t y pe (designated here): India, Nagaland, Kohima, 6000 ft., 21 October 1885, C.B. Clarke 40993A (lower specimen of K000694774!); isolectotypes upper two specimens of K000694774!.

I. mengtszeana Hook. f. in Nouv. Arch. Mus. Hist. Nat. sér. 4, 10: 256. 1908.
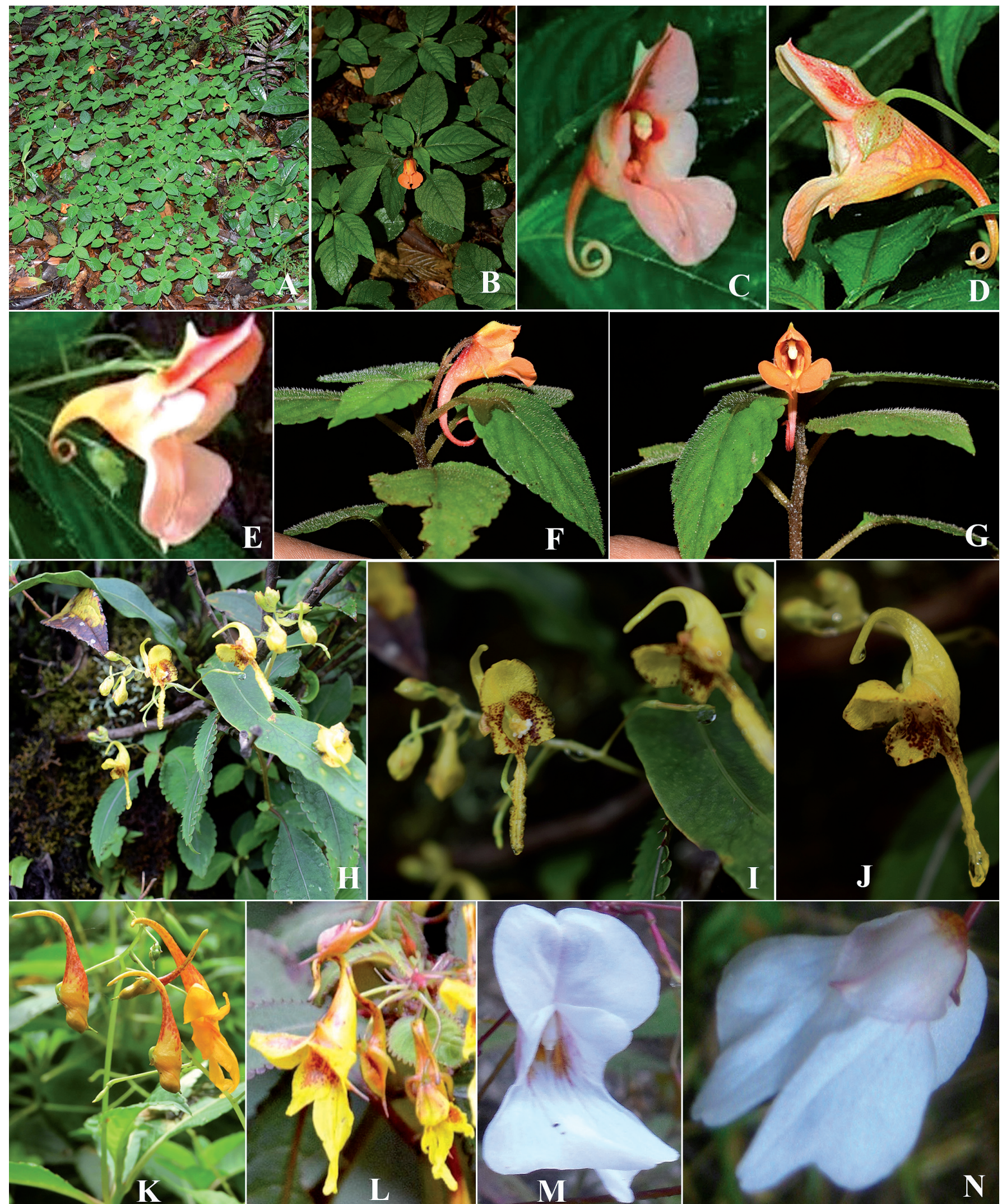

Fig. 12. Impatiens pulchra (A-G), I. scitula (H-J), I. stenantha (K-L), I. violoides (M-N) 
Type citation in the protologue: "YUNNAN; Mont. Mengtsze, alt. 6000 ped. W. Hancock, ex Aug. Henry; Leng-chan-ten. Alt. 7000 ped., n. 11208, et monts Szemov n. 12536 C. D., Aug. Henry: in Herb. Calcutta adsunt numera Henrici 9808, 12536, 12536 B. Herb. Mus. Kew. et Paris".

L e c t o ty pe (designated by D. Verma et al. in J. Jap. Bot. 91: 52. 2016): China, Yunnan, Leng-chan-ten mt., 7000 ft., s.d., A. Henry 11208 (K000199721!); isolectotype NY00406461!.

Re maining syntypes: China, Yunnan, Szemao mts., 5000 ft., s.d., A. Henry 9808 (CAL!); China, Yunnan, Szemao mts., 4500 ft, s.d., A. Henry 12536 (CAL!); China, Yunnan, Szemao mts., s.d., A. Henry $12536 B$ (CAL!); China, Yunnan, Szemao mts., $4000 \mathrm{ft}$, s.d., A. Henry 12536B (E00313607!); China, Yunnan, Szemao, s.d., A. Henry 12536C (E00313608!); China, Yunnan, Szemao mts., $4500 \mathrm{ft}$, s.d., A. Henry $12536 B$ (K000199722!); China, Yunnan, Szemao mts., $5000 \mathrm{ft}$, s.d., A. Henry 12536C (K000199726!); China, Yunnan, Szemao mts., s.d., A. Henry 12536D (K000199727!); China, Yunnan, Mengtsze, 6000 ft., October 1893, W. Hancock 56 (K000694575!); China, Yunnan, Mengtsze, 6000 ft., s.d., A. Henry 9268 (K000694574!); China, Yunnan, Tchen-fong-chan, September 1893, M. Delavay s.n. (P04543653!).

I. monticola Hook. f. in Nouv. Arch. Mus. Hist. Nat. sér. 4, 10: 257. 1908, syn. nov.

Type citation in the protologue: "SZECHUAN; monte Omei, alt. 4000 ped. Pere E. Faber (ex. Herb. Aug. Henry, n. 863), E.-H. Wilson n. 4735, in Herb. Paris et Kew".

Lect otype (designated by D. Verma in Phytotaxa 226: 298. 2015): China, Szechwan, Mount Omei, 4000 ft., s.d., E. Faber 863 (K000199719!).

Remaining syntypes: China, Western China, Mt. Omei, July 1904, E.H. Wilson (K000199718!, P00492344!).

D istribution: Bhutan, China, Myanmar, Thailand and India (northeast Indian states and hilly areas of West Bengal adjacent to Sikkim and Bhutan).

Notes: Impatiens pulchra shows variation in the shape and size of leaves and degree of indumentum. I. annulifera and I. mengtszeana are appropriately synonymized under I. pulchra by Ruchisansakun et al. (1018). Examination of live plants in the field and study of herbarium specimens (including types) of I. burmanica, I. cuspidifera and I. monticola revealed that these taxa are conspecific with I. pulchra (Fig. 12). The lower specimen of K000694774! is designated here as the lectotype for the name I. cuspidifera Hook. f.

The specimens of undescribed name I. stenokalyamma Hook. f., nom. nud. at K (K000694769 and K000694770) are identified as I. pulchra Hook. f. \& Thomson.
24. Impatiens scitula Hook. f. in Rec. Bot. Surv. India 4: 14, 20. 1905.

Type citation in the protologue: "Chumbi; alt?".

Le c t o type (designated here): Tibet, 1882, King's collector s.n. (upper left hand side specimen of K000694941!); isolectotypes CAL! - other three specimens of K000694941!.

I. nummulariifolia Hook. f. in Rec. Bot. Surv. India 4: 14, 20. 1905.

Type citation in the protologue: "Sikkim, alt. 10,000-12000 ft. ?"

L e c t o ty pe (designated here): India, Sikkim, Chooyoung, March 1902, Prain's collector 393 (K000694785!); isolectotype CAL!.

I. pantlingii Hook. f. in Rec. Bot. Surv. India 4: 16, 21. 1905.

Type citation in the protologue: "Sikkim, alt. 10,000 ft."

L e c t o t y p e (designated here): India, Sikkim, Syrugong, September 1901, R. Pantling s.n. (right hand side specimen of K000694940!); isolectotypes CAL! - other specimens of K000694941!.

I. trichocladon Hook. f. in Rec. Bot. Surv. India 4: 21. 1905, syn. nov.

Type citation in the protologue: "Sikkim, alt. 10,000 ft. ?"

L e c t o t y pe (designated here): India, Sikkim, Richi La, 10000 ft., September 1903, Prain's collector 61 (lower side specimen of K000694942!); isolectotypes CAL!, upper side specimen of K000694942!.

I. tubifera Hook. f. in Rec. Bot. Surv. India 4: 57. 1906.

Type citation in the protologue: "Sikkim; on Tonglo, alt. 9,000 ft. J.S. Gamble"

L e c t ot ype (designated here): India, Sikkim, Tonglo, 9000 ft., July 1882, J.S. Gamble 10388 (left hand side specimen of K000694943!); isolectotypes CAL!, right hand side specimen of K000694943!.

D istribution: Bhutan and India (Arunachal Pradesh, Sikkim and hilly areas of West Bengal adjacent to Sikkim and Bhutan).

Notes: For the name Impatiens scitula Hook. f., two herbarium sheets were traced, one each at $\mathrm{K}$ (K000694941) and CAL. The upper left hand side specimen of K000694941, is chosen here as the lectotype. Two sheets were traced for the name I. nuтmulariifolia Hook. f. and the better preserved specimen K000694785, is designated here as the lectotype. The right hand side specimen of K000694940, is chosen here as the lectotype for the name I. pantlingii Hook. f. The lower side specimen of K000694942, is designated here as the lectotype for the name I. trichocladon Hook. f. The left hand side specimen of K000694943, is designated here as the lectotype for the name I. tubifera Hook. f. 
In I. scitula Hook. f., leaves variation from lanceolate to elliptic was observed in Arunachal Pradesh (Fig. 12).

I. trichocladon is similar to Impatiens scitula, both in reproductive and vegetative characters. Therefore, the former is treated here as a synonym of the latter species.

25. Impatiens serrata Benth. ex Hook. f. \& Thomson in J. Proc. Linn. Soc., Bot. 4: 136. 1859.

Type citation in the protologue: "I. serrata (Benth. in Wall. Cat. 4771!). Hab. Umbrosis Himalayae temperatae centralis et orientalis, Nepal! Wallich; Sikkim 8000-10,000 ped.! J. D. H. (fl. Jun.Sept.). (v.v.)".

L e c t o t y p e (designated here): Nepal, 1821, Wallich cat. no. 4771 (larger middle specimen of K001039866!); isolectotypes CAL! - other specimens of K001039866!. I. serrulata Hook. f. in Rec. Bot. Surv. India 4: 7, 10. 1904.

Type citation in the protologue: "Kumaon; Ralam valley, at Saba Udiyar".

Ty p e: India, Uttarakhand, Ralam valley (not traceable.)

D is tribution: Nepal, Tibet and India (Himachal Pradesh and Uttarakhand).

Note s: Hooker $(1859$, l.c. $)$ described Impatiens serrata based on the specimens of Wallich cat. no. 4771 and his own collection of Impatiens no. $88 \& 89$ from Sikkim. Later, in 1903 and 1905, he amended the description of $I$. serrata by excluding the specimens of Impatiens no. 88 and 89 from Sikkim. He described I. falcifera in 1903 (Bot. Mag. 129: t. 7923) based on the collection of Impatiens no. 88 held at $\mathrm{K}$ and, in 1905, described I. serratifolia (Rec. Bot. Surv. India 4: 18, 23) based on the collection of Impatiens no. 89. Furthermore, the specimens of Impatiens no. 88 at $\mathrm{P}$ (P04538486) are of I. stenantha Hook. f. Therefore, the name $I$. serrata Benth. ex Hook. f. \& Thomson is now associated only with the specimens of Wallich cat. no. 4771. The larger middle specimen (larger than three left hand side specimens and two right hand side specimens) of K001039866, is selected here as the lectotype.

26. Impatiens stenantha Hook. f. in Fl. Brit. India 1: 478. 1875.

Type citation in the protologue: "SIKKIM HIMALAYA and E. NIPAL, common, alt. 6-8000 ft.; KHASIA MIS. alt. 5-6000 ft., Griffith, \& c". L e c t otype (designated here): India, Sikkim, 6000-8000 ft., s.d., Impatiens no. 53, J.D. Hooker s.n. (larger upper specimen of K000694611!); isolectotypes CAL!, G00237315!, smaller lower specimen of K000694611!.

Remaining syntypes: India, Sikkim, 600012000 ft., s.d., J.D. Hooker s.n. (K000694610!,
K000694613!); India, East Himalaya, s.d., W. Griffith 1238 (P04538484!).

I. asymmetrica Hook. f. ex Burkill in J. Proc. Asiat. Soc. Bengal 4: 190, f. 5. 1908.

Type citation in the protologue: "Sikkim Himalaya".

Le c t otype (designated here): India, West Bengal, Darjeeling, Jorpokhri, 8,000 ft., 3 October 1906, I.H. Burkill 27742 (larger upper specimen of K000694614!); isolectotypes CAL!, smaller lower specimen of K000694614!.

I. dibangensis Gogoi \& Borah in Webbia 72: 89. 2016, syn. nov.

H o l o t y p e: India, Arunachal Pradesh, Lower Dibang Valley district, Mayodia Pass, 2600 m, 18 September 2012, R. Gogoi \& S. Borah 21870 (CAL!).

D istribution: Bhutan, China, Nepal and India (northeast Indian states and hilly areas of West Bengal adjacent to Sikkim and Bhutan).

N o te s: From the syntype specimens of Impatiens stenantha Hook. f., larger upper specimen of K000694611 is better preserved and is selected here as the lectotype.

The name I. asymmetrica was validly published by I.H. Burkill in J. Proc. Asiat. Soc. Bengal 4: 190, f. 5. 1908. He provided a short description of I. asymmetrica and differentiated it from I. longipes Hook. f. \& Thomson. The larger upper specimen of K000694614 is selected here as the lectotype for the name I. asymmetrica Hook. f. ex Burkill. After a detailed study of herbarium specimens of I. stenantha Hook. f. at different herbaria including types and also ecological study of this species in different localities of northeast India at the altitude range of 1600-3300 m, it was found that I. asymmetrica and $I$. dibangensis are synonymous to $I$. stenantha. In I. stenantha, the spur is usually upcurved, but in some abnormal forms, the straight spur is also seen within the same population (Fig. 12).

27. Impatiens sulcata Wall. in Roxb., Fl. Ind. (Carey \& Wallich ed.) 2: 458. 1824.

Type citation in the protologue: "Discovered at Gosain-Than".

L e c t o t y p e (first-step designated by Y.J. Nasir, Fl. Pakistan 133: 13. 1980): Nepal, Wallich (K, two specimens K001039845 and K001039846 of Wallich cat. no. 4764A); second-step designated here: Nepal, 1821, Wallich cat. no. 4764A (K001039846!).

D i s tr i but i o n: Bhutan, China, Nepal, Pakistan and India (Himachal Pradesh, Jammu \& Kashmir, Sikkim and Uttarakhand).

N o t e s : Wallich (1824) described Impatiens sulcata based on the specimens collected from Gosainthan, Nepal. Nasir in Fl. Pakistan 133: 13. 1980 cited the type for I. sulcata as "Nepal, Wallich (K)" and, in doing so, 
he made an inadvertent lectotypification for the name I. sulcata Wall. However, he did not specify which particular specimen of the herbarium sheet Wallich cat. no. $4764 \mathrm{~A}$ from Nepal at $\mathrm{K}$ is the type specimen, because this herbarium sheet contains two specimens (K001039845 and K001039846). The left hand side specimen (K001039845) is of I. glandulifera Royle and the right hand side specimen (K001039846) of I. sulcata Wall. According to Art. 9.17 of ICN (Turland et al., 2018), Nasir's type citation must be accepted as the firststep lectotypification because it cannot be ascertained which specific specimen at $\mathrm{K}$ was selected by him as the lectotype. Therefore, the specimen K001039846, is designated here as the second-step lectotype, as it agrees well with the protologue and also depicts the taxon as recognised today.

The herbarium sheet of Wallich cat. no. 4764B collected by G. Govan from Sirmore (Sirmaur), Himachal Pradesh, India contains three specimens. The specimens at upper and lower right hand side (K001039847) are of I. glandulifera Royle, and the lower right hand side specimen is of I. sulcata Wall. One more herbarium sheet of Wallich cat. no. 4764 with two specimens (K000694927) exit at K and is of I. sulcata Wall., but place of collection is not clear, either belongs to Wallich cat. no. 4764A from Nepal or Wallich cat. no. 4764B from Sirmaur, Himachal Pradesh, India.

28. Impatiens sulcata var. amplexicaulis (Edgew.) R. Kr. Singh \& D. Borah, comb. et stat. nov.

I. amplexicaulis Edgew. in Trans. Linn. Soc. London 20: 37.1846.

Type citation in the protologue: "Hab. Himala, in umbrosis, alt. ped. 7000-8000. Simla, Sambi.

L e c t o t y p e (designated by S. Akiyama in Bull. Natl. Mus. Nat. Sci., Tokyo, B. 41: 120-121. 2015): India, Himachal Pradesh, Simla, 6000-7000ft., 1844, M.P. Edgeworth 333 (K000694628!).

D istribution: Endemic to India (Himachal Pradesh).

Notes: Impatiens amplexicaulis Edgew. is similar to I. sulcata Wall. in all respects, except the leaves characters, therefore treated here as variety of I. sulcata. In I. sulcata var. sulcata, leaves are petiolate with a cuneate or obtuse base and in I. sulcata var. amplexicaulis, leaves are sessile with an amplexicaul base.

29. Impatiens sulcata var. glandulifera (Royle) R. Kr. Singh \& D. Borah, comb. et stat. nov.

I. glandulifera Royle, Ill. Bot. Himal. Mts. 151, t. 28, f. 2. 1835.

Type citation in the protologue: "This gigantic species, obtained from Cashmere seed, is from its size very inadequately represented at Tab. 28. Fig. 2, and the leaves are not sufficiently lanceolate. It succeeds well, both in the Saharunpore Botanic Garden and the Mussooree Experimental Nursery".

L e c t o type (designated here): "Illustration" Royle, Ill. Bot. Himal. Mts. t. 28, f. 2. 1835.

Distribution: Native of Nepal, Pakistan and India (Himachal Pradesh, Jammu \& Kashmir and Uttarakhand). Introduced as an ornamental plant in many parts of the world, but now, it has become invasive there (Adamowski 2007, 2009).

Note s: Royle $(1835$, l.c.) described Impatiens glandulifera on the basis of the living specimens that flowered in the Saharanpur Botanic Garden and Mussoorie Experimental Nursery, but no type was indicated. Royle's type collections are known to exist at BR, BSD, CAL, CGE, DD, E, G, K, LE, LIV and PH, but after contacting the curators of these herbaria, no herbarium specimen of the living plants based on which the description of I. glandulifera was drawn could be traced. This indicates that either herbarium specimens were not made at all from the living specimens that flowered in the Saharanpur Botanic Garden and Mussoorie Experimental Nursery, or, if made, they are not extant now. Therefore, the coloured plate t. 28 , f. 2 . provided by Royle in the protologue is the only remaining original material and is chosen here as the lectotype.

I. glandulifera Royle is similar to I. sulcata Wall. in all respects, except the shape of capsule, therefore treated here as variety of I. sulcata. In I. sulcata var. sulcata, capsule is linear and cylindrical and in I. sulcata var. glandulifera, capsule is fusiform and broadly clavate.

30. Impatiens thomsonii Hook. f. in J. Proc. Linn. Soc., Bot. 4: 128. 1859.

Type citation in the protologue: "Hab. Himalaya temperata subalpina, Sikkim, alt. 12,000 ped.! J. D. H.; Kumaon et Garwhal, 12,000! St. \& W. (6, 7, 8); Piti! et Kunawur, 9000-10,000 ped.! T.T.”.

L e c t o type (designated here): India, Uttarakhand, Kumaon, 9000-10000 ft., Impatiens no. 68, 26 August 1847, T. Thomson s.n. (lower left hand side specimen of K000694920!); isolectotypes - other specimens of K000694920!.

Remaining syntype: India, Uttarakhand, Kumaon, Milam, 11500 ft., s.d., R. Strachey \& J.E. Winterbottom 6 (K000694921).

I. aitchisonii Hook. f. in Rec. Bot. Surv. India 4: 9. 1904, syn. nov.

I. thomsonii subsp. aitchisonii (Hook. f.) GreyWilson in Fl. Iranica 143: 11. 1979.

H o l o t y pe: Afghanistan, Shendtoi, 9000-10000 ft., August 1879, J.E.T. Aitchison 1005 (K000694923!).

Distribution: Afghanistan, Pakistan, Tibet and India (Himachal Pradesh, Jammu \& Kashmir, Sikkim and Uttarakhand). 
Notes: Impatiens thomsonii was described by Hooker $(1859$, l.c. $)$ based on the specimens from Sikkim and Uttarakhand. Presently, only one original herbarium sheet is extant at $\mathrm{K}$ for the name I. thomsonii Hook. f. This sheet contains the specimens collected from Kumaon by two collectors (K000694920 and K000694921). Of these, the better preserved lower left hand side specimen of K000694920, is designated here as the lectotype. Examination of live plants in fields and study of herbarium specimens reveals that $I$. aitchisonii Hook. f. is conspecific with I. thomsonii.

31. Impatiens tripetala Roxb. ex DC., Prodr. 1: 687. 1824.

Hol oty pe: India, cultivated at Indian Botanic Garden Howrah, July 1818, Anon. s.n. (G00218033!).

I. florigera C.B. Clarke ex Hook. f. in Rec. Bot. Surv. India 4: 13, 19. 1905, syn. nov.

Type citation in the protologue: "Sikkim, alt. 1,000-5,000 ft.".

L e c t o t y pe (designated here): India, Sikkim, Selim, 3000 ft., 12 October 1884, C.B. Clarke 36742A (right hand side specimen of K000694671!); isolectotypes CAL!, left hand side specimen of K000694671!.

I. kamrupana Gogoi, J. Sarma, Borah in Phytotaxa 395: 36. 2019, syn. nov.

H o l o type: India, Assam, Nogedonga, $190 \mathrm{~m}$, 27 September 2018, S. Borah \& J. Sarma 7 (CAL!).

I. longirama Hook. f. in Bull. Misc. Inform. Kew 1910: 297. 1910, syn. nov.

Type citation in the protologue: "MANIPUR. Irang, 1220 m., Nov. 1907, A. Meebold, 5867”. L e c t o type (designated here): India, Manipur, Irong, 4000 ft., November 1907, A. Meebold 5867 (K000694907!).

I. multiflora Benth. ex Hook. f. \& Thomson in J. Proc. Linn. Soc., Bot. 4: 126. 1859.

Type citation in the protologue: "Wall. Cat. 4742!".

L e c t o ty pe (designated by Ruchis. et al. in Blumea 63: 247. 2018): Bangladesh, Pundua, s.d., Wallich cat. no. 4742, F. De Silva s.n. (K001039802!).

Distribution: Bangladesh, Bhutan, Myanmar, Nepal and India (West Bengal and northeast Indian states).

Note s: For the name Impatiens florigera C.B. Clarke ex Hook. f., the right hand side specimen of K000694671 is chosen here as the lectotype. Hooker $(1910$, l.c. $)$ described I. longirama based on the specimens of Meebold 5867 from Manipur. At present, only one specimen of Meebold 5867 from Manipur is extant at K (K000694907), but this specimen is not annotated by J.D. Hooker. This specimen is a part of original collection and, therefore, designated here as the lectotype for the name I. longirama Hook. f.
After the detailed study of herbarium specimens of I. tripetala Roxb. ex DC. at different herbaria and also ecological study of this species in different localities of northeast India, it was found that I. florigera, I. kamrupana and I. longirama are synonymous to I. tripetala. This species is common in all northeast Indian states in different habitats located at the altitude range of 100-1600 $\mathrm{m}$ and shows variation in the nature of indumentum, shape and size of leaves, colour of flower (white-lilac-pink-purplish). and size of lower sepal with spur.

32. Impatiens tuberculata Hook. f. \& Thomson in J. Proc. Linn. Soc., Bot. 4: 155. 1859.

Type citation in the protologue: "Hab. Himalaya orientali temperata et subalpina, Sikkim, alt. 10,000-13000 ped.! J. D. H. (fl. Aug.-Sept.). (v.v.)". L e c t ot y pe (designated here): India, Sikkim, 1000014000 ft., s.d., Impatiens no. 61, J.D. Hooker s.n. (right side specimen of K000694904!); isolectotypes CAL!, left side specimen of K000694904!, L0389795!, P04538508!.

I. aganantha Hook. f. in Rec. Bot. Surv. India 4: 16, 21. 1905.

Type citation in the protologue: "Chumbi, alt.?".

L e c t o type (designated here): Tibet, Chumbi, Luig moo loug, 31 July 1884, King's collector 145 (K000694905!); isolectotype CAL!.

D istribution: Bhutan, Tibet and India (Sikkim).

Notes: The better preserved, right side specimen of K000694904 is designated here as the lectotype for the name Impatiens tuberculata Hook. f. \& Thomson. For the name I. aganantha Hook. f., K000694905 is designated here as the lectotype.

33. Impatiens violoides Edgew. ex Hook. f. in Rec. Bot. Surv. India 4: 5, 8-9. 1904.

Type citation in the protologue: "Between Pikha and Janglig (Kumaon ?), October, 1834.

L e c t ot ype (designated here): India, Uttarakhand, Kumaon, Junglung, 7000 ft., 1844, M.P. Edgeworth 342 (K000694928!).

D istribution: Endemic to India (Himachal Pradesh and Uttarakhand).

Notes: Only one original specimen is extant at $\mathrm{K}$ (K000694928) for the name Impatiens violoides Edgew. ex Hook. f. and is designated here as the lectotype, as it agrees well with the protologue. The petals of this species are similar to I. glandulifera Royle and I. sulcata Wall., but differ in the flower colour and shape of lower sepal. The colour of I. violoides flowers is white with light pink-purple tinge and lower sepal is navicular with beaked mouth and lacks spur (Fig. 12). 
Acknowledgements. The first author is thankful to the Director, Botanical Survey of India, Kolkata and the Head of Office, Botanical Survey of India, Southern Regional Centre, Coimbatore for facilities. The second and third authors are grateful to the Botany Department, Rajiv Gandhi University, Arunachal Pradesh for providing facilities to carry out the study, and to Mr. Ozar Taku, Mr. Ritanso Khambrai and Mr. Neelam Gap for their help during the field explorations.

\section{Author Contributions}

Research concept and design: R. K. Singh \& D. Borah Acquisition and/or assembly of data: R. K. Singh, D. Borah \& M. Taram

Data analysis and interpretation: R. K. Singh, D. Borah \& M. Taram

Drafting the article: R. K. Singh \& D. Borah

Critical revision: R. K. Singh

Final approval: R. K. Singh

\section{References}

AdAmowski W. 2007. Balsams on the offensive: the role of planting in the invasion of Impatiens species. In: B. Tokarska-Guzik, J. H. Brock, G. Brundu, L. Child, C. C. DAeHler \& P. PyšEk (eds.). Plant invasions: human perception, ecological impacts and management, pp. 57-70. Backhuys Publishers, Leiden.

Adamowski W. 2009. Impatiens balfourii as an emerging invader in Europe. Neobiota 8: 183-194.

Arigela R. K., Singh R. K. \& Kabeer K. A. A. 2019. Impatiens tanyae (Balsaminaceae), a new species from Western Ghats, India. Kew Bulletin 74(3): 48(1-7). https://doi.org/10.1007/s12225-019-9831-4

Bhaskar V. 2012. Taxonomic monograph on Impatiens L. (Balsaminaceae) of Western Ghats, South India. Centre for plant taxonomic studies, Bangalore.

Chen Y. L., Akiyama S. \& Ohba H. 2007. Balsaminaceae. In: Z. Y. Wu \& P. H. RAVEn (eds.). Flora of China, Vol. 12, pp. 43-114. Science Press, Beijing and Missouri Botanical Garden Press, St. Louis, USA.

Gogoi R., Borah S., Dash S. S. \& Singh P. 2018. Balsams of eastern Himalaya, a regional revision. Botanical Survey of India, Kolkata.

Gogor R. \& Sherpa N. 2020. Taxonomic identity of Impatiens cathcartii Hook.f. \& I. serratifolia Hook.f. with notes on typification of both names. Biodiv. Res. Conserv. 59: 1-8. https://doi.org/10.2478/biorc-2020-0008

Grey-Wilson C. 1991. Balsaminaceae. In: A. J. C. Grierson \& D. G. Long (eds.). Flora of Bhutan, Vol. 2, pp. 82102. Royal Botanic Garden, Edinburgh.

Hooker J. D. 1875. Flora of British India, Vol. 1. L. Reeve and Co., London.

Hooker J. D. 1904-1906. An epitome of the British Indian species of Impatiens. Records of the Botanical Survey of India 4: 1-58.

Powo 2020. Plants of the World Online. Facilitated by the Royal Botanic Gardens, Kew. Retrieved from: http:// www.plantsoftheworldonline.org/ (accessed 12 October 2020).
Rahelivololona E. M., Fischer E., Janssens S. B. \& RazafiMANDIMBison S. G. 2018. Phylogeny, infrageneric classification and species delimitation in the Malagasy Impatiens (Balsaminaceae). PhytoKeys 110: 51-67. https://doi.org/10.3897/phytokeys.110.28216

Ruchisansakun S., Suksathan P., Van Der Niet T., Smets E. F., SAw-Lwin, Janssens S. B. 2018. Balsaminaceae of Myanmar. Blumea 63: 199-267. https://doi. org/10.3767/blumea.2018.63.03.01

SINGH R. K. 2016a. Notes on author attribution and typification of two names of Impatiens (Balsaminaceae). Journal of Japanese Botany 91(4): 237-241.

SingH R. K. 2016b. Typification of thirty six names of thirty five recognized taxa in Impatiens (Balsaminaceae), endemic to Western Ghats. Phytotaxa 268(3): 167180. https://doi.org/10.11646/phytotaxa.268.3.1

SiNGH R. K. 2017. Lectotypification of three Linnaean names in Impatiens (Balsaminaceae). Phytotaxa 321(3): 299-300. https://doi.org/10.11646/phytotaxa.321.3.8

Singh R. K. \& Garg A. 2016. Call for conservation of the critically endangered saffron balsam of Karnataka Impatiens raziana Bhaskar and Razi (Balsaminaceae). Indian Forester 142(8): 803-805.

Turland N. J., Wiersema J. H., Barrie F. R., Greuter W., Hawksworth D. L., Herendeen P. S., Knapp S., Kusber W.-H., Li D.-Z., Marhold K., May T. W., Mcneill J., Monro A. M., Prado J., Price M. J. \& Smith G. F. 2018. International Code of Nomenclature for algae, fungi, and plants (Shenzhen Code). Regnum Vegetabile 159. Koeltz Botanical Books, Glashütten. https:// doi.org/10.12705/Code.2018

Wallich N. 1824. Impatiens. In: W. CARey \& N. Wallich (eds.). Flora Indica; or Descriptions of Indian Plants, by the Late William Roxburgh, Vol. 2, pp. 452-465. The Mission Press, Serampore. 